1 An experimental investigation of $\mathrm{C}-\mathrm{O}-\mathrm{H}$ fluid-driven carbonation of serpentinites under

\title{
forearc conditions
}

Sieber M. J. ${ }^{1 *}$, Hermann J. ${ }^{2}$, Yaxley G.M. ${ }^{1}$

1 Research School of Earth Science, The Australian National University, Canberra, 2601, Australia

2 Institute of Geological Sciences, University of Bern, 3012 Bern, Switzerland

*corresponding author: E-mail address: melanie.sieber@anu.edu.au

\section{Abstract}

The carbonation of serpentinites in the forearc region of the mantle wedge in subduction zones and of serpentinites within the subducting slab by fluids derived from prograde dehydration and decarbonation have important implications for the deep Earth carbon cycle. This study shows that the carbonation of serpentinites under the forearc can establish, over time, a significant reservoir for carbon within a partially hydrated mantle wedge and that carbonation of (ultra-) mafic rocks within the subducting slab contributes to C-transfer to greater depths and might supply carbon for arc volcanism or the deep mantle.

We report a new high pressure experimental investigation of the interactions between oxidised $\mathrm{C}-\mathrm{O}-\mathrm{H}$ fluids and serpentinite and model the reaction progress with time series experiments. The $\mathrm{CO}_{2}, \mathrm{H}_{2} \mathrm{O}$ and alkane $\left(\mathrm{C}_{\mathrm{n}} \mathrm{H}_{2 \mathrm{n}+2}, \mathrm{n}=1-6\right.$; e.g. methane, ethane $)$ contents in the fluid phase from quenched experimental run products have been analysed by gas chromatography and the results are compared with thermodynamic calculations. With progressive carbonation, the formation of magnesite + chlorite together with quartz, quartz + talc or talc at $1-2 \mathrm{GPa}$ and $500-650{ }^{\circ} \mathrm{C}$ was observed. At temperatures above antigorite stability $\left(\mathrm{T} \gtrsim 700^{\circ} \mathrm{C}\right.$ and $\left.2 \mathrm{GPa}\right)$ magnesite + chlorite is stable together with talc, talc + enstatite, enstatite or enstatite + forsterite for decreasing $\mathrm{CO}_{2}$-content in the fluid. 
Carbonation of serpentinite is a rapid process where magnesite forms within the first hour of the experiments, filtering $\mathrm{CO}_{2}$ from the fluid effectively and equilibrium is approached within

$48 \mathrm{~h}$. The $\mathrm{CO}_{2}$-sequestration and magnesite production are less pronounced at higher temperatures. Therefore, $\mathrm{C}-\mathrm{O}-\mathrm{H}$ fluids released under subarc conditions might migrate through the mantle with only minor changes in their carbon budget whereas significant carbonation likely occurs under the forearc. Furthermore, partition coefficients for $\mathrm{Ca}, \mathrm{Ba}, \mathrm{Sr}$ and $\mathrm{Pb}$ between magnesite and a $\mathrm{C}$-poor aqueous fluid have been established to demonstrate the potential of newly formed magnesite to sequester fluid mobile elements.

\section{Highlights}

Quantitative C-O-H analyses of fluids after piston cylinder experiments

Carbonation of serpentinites in the forearc region of the mantle wedge

Carbonation is rapid and occurs within the first hour of the experiments

Magnesite is a good monitor for $\mathrm{Ca}, \mathrm{Ba}, \mathrm{Sr}$ and $\mathrm{Pb}$ in subduction zone fluids

\section{Keywords}

Deep carbon cycle

Carbonation

Serpentinites

Forearc

C-O-H fluid

Partitioning

\section{Introduction}

A key aspect of the deep carbon cycle is how exogene carbon may be fixed in oceanic lithosphere via hydrothermal alteration of oceanic crust, subducted into the mantle and then recycled within subduction zones (Berner, 1999; Hayes and Waldbauer, 2006; Kelemen and 
Manning, 2015). Large amounts of carbon stored in marine sediments and altered oceanic crust are transported into the Earth's mantle at subduction zones. Through decarbonation, carbonate dissolution and partial melting, a poorly constrained fraction of carbon is released into fluids and melts during subduction (Poli, 2015) and some carbon is returned to shallower reservoirs (e.g. crust, biosphere and atmosphere), but some carbon is subducted deeper and may be sequestered in the deep mantle (Yaxley and Green, 1994). The magnitudes of the various carbon fluxes and reservoirs have been investigated in several studies (see discussions in Collins et al. (2015); Dasgupta and Hirschmann (2010); Kelemen and Manning (2015)) but remain controversial.

In the absence of fluids and for typical subducting slab geotherms, carbonates are stable and refractory. The stability of carbonates at high pressures has been demonstrated in experimental studies on carbonated peridotites and eclogites (Brey et al., 2008; Yaxley and Brey, 2004; Yaxley and Green, 1994). The transport of carbon to greater depths has further been evidenced by stable isotope and mineral inclusions data in some diamonds (Stachel and Harris, 2008).

However, carbonates can dissolve into aqueous fluids (Caciagli and Manning, 2003; Dolejs and Manning, 2010), released during subduction. The capacity of the slab to produce such aqueous fluids is pronounced at an early stage of subduction, because prograde metamorphism leads to dehydration reactions. Thermodynamic models have shown that carbon is released as $\mathrm{CO}_{2}$ from carbonated rocks especially when externally derived hydrous fluids infiltrate them (Gorman et al., 2006; Kerrick and Connolly, 2001a; Kerrick and Connolly, 2001b). The amount of $\mathrm{CO}_{2}$ in fluids is higher under forearc $\left(\mathrm{X}_{\mathrm{CO}_{2}} \leq 0.7\right)$ compared to subarc $\left(\mathrm{X}_{\mathrm{CO}_{2}} \leq 0.21\right)$ conditions as shown in experimental studies $\left(\mathrm{X}_{\mathrm{CO}_{2}}=\frac{n_{\mathrm{CO}_{2}}[\mathrm{~mol}]}{n_{\mathrm{CO}_{2}}[\mathrm{~mol}]+n_{\mathrm{H}_{2} \mathrm{O}}[\mathrm{mol}]} ;\right.$ Molina and Poli (2000); Poli (2015); Poli et al. (2009)). Such 
$\mathrm{C}-\mathrm{O}-\mathrm{H}$ fluids might interact with the surrounding slab lithologies and (ultra-) mafic rocks in the overlying mantle wedge causing carbonation. Field observations demonstrate the importance of $\mathrm{C}-\mathrm{O}-\mathrm{H}-\mathrm{fluid}$ driven carbonation in the slab and overlying mantle wedge (Ague and Nicolescu, 2014; Beinlich et al., 2012; Bjerga et al., 2015; Piccoli et al., 2016; Scambelluri et al., 2016).

This study focuses on the potential capacity of serpentinites to store carbon as carbonates when $\mathrm{C}-\mathrm{O}-\mathrm{H}$ bearing fluids released from the slab migrate into and interact with the partially serpentinized mantle and serpentinites in the slab (Hyndman and Peacock, 2003; Kerrick and Connolly, 1998; Tumiati et al., 2013). Carbon concentrations in fluids are poorly constrained, because earlier experimental studies were often inhibited by the inability to precisely measure the volatile compositions in equilibrium with the solid phases. To analyse the volatile species in $\mathrm{C}-\mathrm{O}-\mathrm{H}$ fluids from experimental capsules Tiraboschi et al. (2016) used a mass spectrometer based technique and computed the obtained mass/charge signal into volatile concentrations.

In this study, we measured directly the C-O-H fluid species in quenched experimental fluids by gas chromatography using an inlet system, that allows the experimental capsule to be pierced under vacuum and the gas phase to be extracted (Martin and Hermann, in press). We compare the measured volatile fluid compositions with thermodynamic calculations and show to what extent the behaviour of real fluids containing dissolved species like $\mathrm{CO}_{3}{ }^{2-}, \mathrm{Si}^{4+}$ and $\mathrm{Mg}^{2+}$ can be approximated by pure $\mathrm{CO}_{2}-\mathrm{H}_{2} \mathrm{O}$ fluids assumed in the model. We demonstrate how fast the formation of carbonates reduces the amount of $\mathrm{CO}_{2}$ in the fluids by investigating the kinetics of the carbonation reaction through time series experiments. We further show the potential of newly formed magnesite to sequester $\mathrm{Ca}$ and fluid mobile trace elements such as $\mathrm{Ba}, \mathrm{Sr}$ and $\mathrm{Pb}$ and show to what extent they may become enriched in carbonated ultramafic rocks. Our results are important to constrain carbon fluxes in subducted ultramafic rocks and 
the mantle wedge as we demonstrate that the forearc mantle may, over time, become an important and previously unrecognised reservoir for carbon, whereas carbonation in the subarc is less pronounced.

\section{Experimental methods}

Piston cylinder experiments were performed using powdered natural serpentinite $(>98 \%$ antigorite, traces of magnetite and no sulfides according to XRD) mixed with various amounts of oxalic acid dihydrate (OAD; abbreviations are listed in the supplementary information) as the main source of $\mathrm{H}_{2} \mathrm{O}$ and $\mathrm{CO}_{2}$. Four starting mixes (SP1-4) with various serpentinite/fluid ratios were used (Table 1). $\mathrm{Ba}, \mathrm{Pb}, \mathrm{Sr}$ and $\mathrm{Ca}$-carbonate were added in trace and minor abundances (Table 1). See supplementary information for details of preparation and performance of the piston cylinder experiments.

Table 1

Experiments were run at 1 and $2 \mathrm{GPa}$, between $500-750^{\circ} \mathrm{C}$ for $48 \mathrm{~h}$. Two sets of time series experiments, both using SP1, were performed at $600^{\circ} \mathrm{C}, 2 \mathrm{GPa}$ for 24,48 and $72 \mathrm{~h}$ and at $550^{\circ} \mathrm{C}, 1 \mathrm{GPa}$ for $0.1,0.42,0.85,1,48$ and $192 \mathrm{~h}$.

\section{Analytical Methods}

After the piston cylinder experiments, the composition of the fluid in the recovered capsules was analysed by gas chromatography (GC-TCD). Then the capsules were mounted, polished and C-coated for electron microscopy (SEM and EPMA). Afterwards, LA-ICP-MS was used to determine the trace element composition of the solid assemblage on selected runs. The presence of particular mineral phases was verified by powder X-ray diffraction (XRD) for selected samples. The details of these techniques are reported in the supplementary information. 
Gas-chromatography was applied to identify and quantify the amount and composition of the volatile species in post-run fluids. A sample-inlet system connected to a gas-chromatograph allows capsules recovered after piston cylinder experiments to be pierced under vacuum and the released gas can be analysed (Figure S1 in the supplementary information). For analysing the gas composition of post-run fluids, the sample holder is first heated to $\sim 150^{\circ} \mathrm{C}$ for $\sim 10$ min and then pierced under vacuum. Heating is necessary to guarantee that all volatiles can escape from the sample. The pressure is sensed at constant temperature $\left(\Delta \mathrm{T} \sim 2^{\circ} \mathrm{C}\right.$ per analytical session; temperature range over all analyses $\left.\sim 130-160^{\circ} \mathrm{C}\right)$ and volume. This pressure is proportional to the amount of the released sample gas according to the ideal gas law. The sample gas is then topped up with pure He gas to above atmospheric pressure ( 140 $\mathrm{kPa}$ ). The gas mixture (sample plus $\mathrm{He}$ ) is homogenized after waiting $\sim 60$ min at constant temperature. Aliquots of this gas mixture are then progressively introduced into, and analysed with the connected GC-TCD 5-7 times showing a reproducibility of $\sim 19 \%$. This routine was used for measuring both standards and samples.

$\mathrm{CO}_{2}$ was calibrated using pure $\mathrm{CO}_{2}$ as a standard and alkanes were calibrated using a certificated standard containing $1000 \mathrm{ppm}$ of each component $\left(\mathrm{C}_{\mathrm{n}} \mathrm{H}_{2 \mathrm{n}+2}, \mathrm{n}=1-6\right)$ in helium. For the $\mathrm{H}_{2} \mathrm{O}$-calibration, Pt-capsules filled with Milli-Q water were prepared in the same fashion as the experimental capsules. The standard calibration was performed with similar concentrations to those expected to be measured from the samples. The standard gases were therefore strongly diluted with pure $\mathrm{He}$ (Figure 1 and supplementary for absolute concentrations). The relation between standard present in the sample inlet chamber and the GC-TCD signal intensity is shown in Figure 1 for $\mathrm{H}_{2} \mathrm{O}$ and $\mathrm{CO}_{2}$ and in Figure $\mathrm{S} 2$ for the alkanes. The GC settings have been optimized to separate and satisfactorily resolve $\mathrm{CO} /$ air, $\mathrm{CH}_{4}, \mathrm{CO}_{2}, \mathrm{C}_{2} \mathrm{H}_{6}, \mathrm{H}_{2} \mathrm{O}$, propane, n-butane, n-pentane and hexane (Figure $\mathrm{S} 3$ ). The peak area is 
a function of the amount of elute in a gas. Gas behaviour was found to be ideal at any stage (see supplementary information).

Figure 1

The post-run fluids in this study contain only two volatile compounds $\left(\mathrm{CO}_{2}\right.$ and $\left.\mathrm{H}_{2} \mathrm{O}\right)$. The $\mathrm{CO}_{2}$ calibration has been used to determine the molar proportion of $\mathrm{CO}_{2}$ in the fluid. $\mathrm{H}_{2} \mathrm{O}$ subsequently makes up the remaining fluid. The total molar amount of the extracted fluid was calculated using the ideal gas law from the measured sample pressure and hence the absolute concentrations of $\mathrm{H}_{2} \mathrm{O}$ and $\mathrm{CO}_{2}$ in the fluid can be calculated from the molar proportions (see formula in the supplementary information).

\section{Thermodynamic calculations}

Temperature- $\mathrm{X}_{\mathrm{CO}_{2}}$ sections have been calculated with Perple_X using a gridded minimization strategy and linear programming for optimization (Connolly, 2005) to constrain the reactions of serpentine with a $\mathrm{CO}_{2}-\mathrm{H}_{2} \mathrm{O}$ fluid. The calculations were simplified to the FMASCH-system using the volatile-free bulk composition $\left(\mathrm{FeO}-\mathrm{MgO}-\mathrm{SiO}_{2}-\mathrm{Al}_{2} \mathrm{O}_{3}\right)$ of the primary antigorite as measured with EPMA (Table S1) saturated with a $\mathrm{CO}_{2}+\mathrm{H}_{2} \mathrm{O}$ fluid. Magnetite $(<<2 \mathrm{wt} \%)$ was not considered in the modelling, because it did not participate in the reactions (see discussion). Minor amounts of $\mathrm{Ca}$ (introduced by the fluid) were also excluded (see supplementary). The Holland and Powell (1998) database and the Holland and Powell (1991) and (1998) model for the fluid equation of state were used. Solid solution models for phase A, brucite, chlorite, clinohumite, olivine, orthopyroxene, magnesite, talc, staurolite, wuestite (Holland and Powell, 1998), antigorite (Padrón-Navarta et al., 2013) and clino- and ortho-amphibole (Diener et al., 2007) have been used in the thermodynamic calculations. This consistent set of solution models takes Fe-Mg exchange between magnesite 
and silicates into account, as well as the tschermak exchange in chlorite, talc and antigorite. Calculations were performed at 1 and $2 \mathrm{GPa}$ between $400-800^{\circ} \mathrm{C}$ for $0 \leq \mathrm{X}_{\mathrm{CO}_{2}} \leq 0.2$.

\section{Results}

\subsection{Textures}

The reaction of serpentine with $\mathrm{CO}_{2}$-rich fluids produced a variety of secondary phases depending on pressure, temperature and fluid/rock ratio. Magnesite is commonly fine grained $(<10 \mu \mathrm{m})$ with a few exceptions $(<30 \mu \mathrm{m})$. Talc is usually fibrous and fine-grained chlorite occurs interstitially. Quartz forms small, subhedral crystals and occurs in a granular texture together with magnesite. Orthopyroxene crystals are often elongated with maximum dimensions ranging between $\sim 15-30 \mu \mathrm{m}$. Remaining antigorite, if present, is coarser grained $(>25 \mu \mathrm{m})$ than any secondary phases and anhedral. Primary magnetite shows unreacted grain boundaries (Figure S4 in supplementary). The porosity is generally high as the fluid volume varies between $\sim 6-16$ vol\% (fluid volume was calculated assuming the fluid behaves as an ideal gas at high pressure and temperature, and therefore reflects an estimate of the maximum volume).The textures of selected runs are illustrated with BSE-images and overlapping EDS element maps of $\mathrm{Mg}$, Si and $\mathrm{Al}$ distributions in Figure 2.

\section{Figure 2}

\subsection{Phase assemblages}

Starting mixture SP1 was used for all experiments at $1 \mathrm{GPa}$ (temperature ranging from 500-650 $\left.{ }^{\circ} \mathrm{C}\right)$. Magnesite + talc + chlorite + antigorite were observed in all experiments at $1 \mathrm{GPa}$, where equilibrium was reached (run time $\geq 48 \mathrm{~h}$, Figure $3 \mathrm{a}$ ). The reaction (1) forming this assemblage in a simplified MSHC system is as follows: 


$$
\begin{array}{llll}
2 \mathrm{Mg}_{3} \mathrm{Si}_{2} \mathrm{O}_{5}(\mathrm{OH})_{4} & +3 \mathrm{CO}_{2}= & 3 \mathrm{MgCO}_{3}+\mathrm{Mg}_{3} \mathrm{Si}_{4} \mathrm{O}_{10}(\mathrm{OH})_{2} & +3 \mathrm{H}_{2} \mathrm{O} \\
2 \text { Antigorite } & +3 \mathrm{CO}_{2}^{\text {fluid }}= & 3 \text { Magnesite } & + \text { Talc }
\end{array}
$$

190 Note that chlorite formed in all experiments due to the presence of minor aluminium in the 191 natural antigorite used in the starting mixtures.

For experiments at $2 \mathrm{GPa}$, four different starting mixtures were used with various $\mathrm{H}_{2} \mathrm{O}+\mathrm{CO}_{2}$-fluid to serpentinite ratios (Table 1), but maintaining $\mathrm{X}_{\mathrm{CO}_{2}}$ at 0.5 in the starting fluid. The measured fluid compositions are shown together with the observed reaction products in Figure 3. Depending on the starting composition and temperature, different phase assemblages were observed (Figure 3b). Magnesite + talc + chlorite + quartz was observed at $550^{\circ} \mathrm{C}$ using SP1 and at $600^{\circ} \mathrm{C}$ and $650^{\circ} \mathrm{C}$ using SP2. This assemblage is formed via reaction (2) in the simplified MSCH-system:

$$
\begin{array}{lllll}
3 \mathrm{Mg}_{3} \mathrm{Si}_{2} \mathrm{O}_{5}(\mathrm{OH})_{4} & +6 \mathrm{CO}_{2}=6 \mathrm{MgCO}_{3}+\mathrm{Mg}_{3} \mathrm{Si}_{4} \mathrm{O}_{10}(\mathrm{OH})_{2} & +2 \mathrm{SiO}_{2}+5 \mathrm{H}_{2} \mathrm{O} \\
3 \text { Antigorite } & +6 \mathrm{CO}_{2}^{\text {fluid }}=6 \text { Magnesite } & + \text { Talc } & +2 \text { Quartz } & +5 \mathrm{H}_{2} \mathrm{O}^{\text {fluid }}
\end{array}
$$

Quartz-free assemblages of magnesite + talc + chlorite (1) were crystallised at $600^{\circ} \mathrm{C}$ for SP1, $630^{\circ} \mathrm{C}$ for SP4, $650^{\circ} \mathrm{C}$ for SP3 and at $700^{\circ} \mathrm{C}$ and $750^{\circ} \mathrm{C}$ for SP2. Within these experiments relicts of primary antigorite persisted below $650^{\circ} \mathrm{C}$ and at $650^{\circ} \mathrm{C}$ for the experiment with higher $\mathrm{X}_{\mathrm{CO}_{2}}$. In the experiments $\geq 700^{\circ} \mathrm{C}$ using SP3 and SP4, enstatite was found for $\mathrm{X}_{\mathrm{CO}_{2}}<$ 0.1. At $700^{\circ} \mathrm{C}$ magnesite + talc + chlorite + enstatite + antigorite were present. Using SP4 as starting material, a talc-free assemblage of magnesite + chlorite + enstatite was observed that can be explained via reaction (3).

$$
\begin{aligned}
& \mathrm{Mg}_{3} \mathrm{Si}_{2} \mathrm{O}_{5}(\mathrm{OH})_{4}+\mathrm{CO}_{2}=\mathrm{MgCO}_{3}+2 \mathrm{MgSiO}_{3}+2 \mathrm{H}_{2} \mathrm{O} \\
& \text { Antigorite } \\
& +\mathrm{CO}_{2}^{\text {fluid }}=\text { Magnesite }+2 \text { Enstatite }+2 \mathrm{H}_{2} \mathrm{O}^{\text {fluid }}
\end{aligned}
$$


At higher temperatures $\left(750^{\circ} \mathrm{C}\right)$ the assemblage using SP4 was likewise free of talc but contained forsterite (magnesite + chlorite + enstatite + forsterite). All experiments contain some relicts of minor, primary magnetite.

Figure 3

\subsection{Gas chromatograph results}

An innovative aspect and significant advantage of this study is the direct analysis of the gas present in the capsule after the experiment by gas chromatography. From the occurrence and abundances of different $\mathrm{C}-\mathrm{O}-\mathrm{H}$ species such as $\mathrm{CH}_{4}, \mathrm{CO}_{2}$ and $\mathrm{H}_{2} \mathrm{O}$, conclusions about the redox conditions, reaction progress and approach to equilibrium can be obtained. The fluid in this study is exclusively comprised of $\mathrm{CO}_{2}$ and $\mathrm{H}_{2} \mathrm{O}$ and in the following, $\mathrm{X}_{\mathrm{CO}_{2}}$ refers to the molar proportion of $\mathrm{CO}_{2}$ in the fluid. Figure 3 shows the phase assemblages as a function of measured post-run $\mathrm{X}_{\mathrm{CO}_{2}}$ and temperature for 1 and $2 \mathrm{GPa}$.

At $1 \mathrm{GPa}$, magnesite + talc + chlorite + antigorite (Figure 3a) are stable with $\mathrm{X}_{\mathrm{CO}_{2}}$ increasing from 0.017 to 0.14 as temperature increases from 500 to $650^{\circ} \mathrm{C}$. Likewise at $2 \mathrm{GPa}$, this assemblage of secondary phases (Figure $3 b$ ) is stable at higher $\mathrm{X}_{\mathrm{CO}_{2}}(0.022-0.116)$ with increasing temperature $\left(600-750^{\circ} \mathrm{C}\right)$. Quartz is additionally present when the fluid contains more $\mathrm{CO}_{2}$ at the same PT. At temperatures $\gtrsim 700^{\circ} \mathrm{C}$ (at $2 \mathrm{GPa}$ ) antigorite starts to dehydrate to enstatite and forsterite. At $700^{\circ} \mathrm{C}$ and $\mathrm{X}_{\mathrm{CO}_{2}}=0.053$, talc (and antigorite) are still present together with enstatite + magnesite + chlorite. At lower $\mathrm{X}_{\mathrm{CO}_{2}}=0.031$ talc (and antigorite) are absent and the proportion of chlorite is strongly reduced due to the incorporation of $\mathrm{Al}$ into enstatite. Magnesite + enstatite + forsterite + chlorite are stable at $750^{\circ} \mathrm{C}$ and $\mathrm{X}_{\mathrm{CO}_{2}}=$ 0.076 .

\subsection{Major element compositions}


The $\mathrm{Mg}$-number $[\mathrm{Mg} \#=100 *$ atomicMg/( $\mathrm{Mg}+\mathrm{Fe})]$ of antigorite used in the starting material is $92.1 \pm 0.5$ and is maintained in the bulk assemblage after the experiment (Table S3). Relicts of antigorite and magnetite in the post-run assemblages are chemically and texturally indistinguishable from the starting material and likely represent unreacted phases (Table S1, Figure S4).

Magnesite shows the largest range in $\mathrm{Mg} \#$ over all runs $(\mathrm{Mg} \#=91.7,2 \sigma=5.4)$ and in individual runs with a variation over a similar range. Nevertheless, single magnesite grains are homogenous. No systematic correlation between the $\mathrm{Mg \#}$ of magnesite and the phase assemblage could be found. The variation in $\mathrm{Mg \#}$ in talc over all runs is, in comparison to

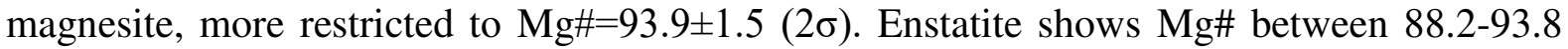

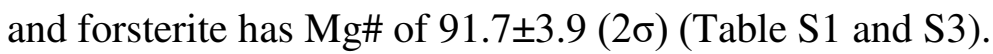

Chlorite $(\mathrm{Mg} \#=93.3 ; 2 \sigma=2.9)$ takes up most of the $\mathrm{Al}$, although talc contains a median of $1.5 \pm 1.1 \mathrm{wt} \% \mathrm{Al}_{2} \mathrm{O}_{3}$. The fine grain size and interstitial texture of chlorite makes it challenging to obtain a pure chlorite analysis by EPMA. Overlap with surrounding phases (e.g. talc, antigorite) might affect chlorite analyses as shown in Figure S5. This makes it difficult to determine the true extent of solid solutions in chlorite and only a fraction (marked with small cyan stars in Figure S5) of all chlorite analyses close to the clinochlore endmember were considered as clean analyses. The presence of chlorite was verified in all XRD scans on selected runs.

\subsection{Mass balance and phase proportions}

The gas analyses not only allow the calculation of the molar proportion of $\mathrm{CO}_{2}$ in the fluid, but also give the absolute abundances of $\mathrm{CO}_{2}$ and $\mathrm{H}_{2} \mathrm{O}$ in the fluid if all fluid can be extracted from the capsule. This allows mass balance calculations including solid and fluid phases assuming that the amount of dissolved solutes in the fluid is minor. The measured amount of 
fluid, however, represents a minimum value, but the relative modal amounts of $\mathrm{CO}_{2}$ and $\mathrm{H}_{2} \mathrm{O}$ are unaffected by incomplete fluid-extraction. Therefore, mineral and fluid proportions were established by processing BSE-images and elemental maps using the software ImageJ for solid phases and the measured $\mathrm{X}_{\mathrm{CO}_{2}}$ combined with mass balance for the fluid phase (Table 2). The solid phase proportions obtained by image processing are within uncertainty consistent with the results from the full mass-balance approach using the amount of extracted fluid. For the calculations, the median major element abundance as measured by EPMA and SEM for each phase in each individual run was used (see Table S3). The exception to this was chlorite, for which the median composition over all accepted EPMA analyses (stars in Figure S5) was used if precise analyses were not obtained. The listed absolute errors in $\mathrm{X}_{\mathrm{CO}_{2}}$ (Table 2) were calculated using Gaussian error propagation including the errors from the balance, GCTCD and EPMA measurements.

Table 2

The abundances of magnesite formed at equilibrium most importantly depend on the bulk $\mathrm{CO}_{2}$-concentration to serpentinite ratio. Therefore, experiments performed using SP2 are highest in magnesite and SP4 lowest (Figure 4, Table 2). The $\mathrm{CO}_{2}$-fluid composition at equilibrium (as a function of temperature and pressure) further determines the amount of magnesite in an inverse correlation. The abundances of other solid phases are determined by the chemical reactions (1-3) that describe the transition from the starting antigorite to the observed equilibrium assemblage.

Figure 4

\subsection{Time series}

Two time-series were performed to investigate the reaction progress and fluid evolution over time. The same starting mix (SP1) was used in both time-series; one was performed at $600^{\circ} \mathrm{C}$, 
$2 \mathrm{GPa}$ for 24,48 and $72 \mathrm{~h}$ and the second at $550^{\circ} \mathrm{C}, 1 \mathrm{GPa}$ for $0.1,0.42,0.85,1,48$ and $192 \mathrm{~h}$. The measured fluid compositions and obtained phase assemblages are displayed as a function of time in Figure 5.

Figure 5

The assemblages and measured fluid compositions in the runs at 1 and 2 GPa do not differ from each other within error, suggesting that equilibrium was approached after $48 \mathrm{~h}$. The shorter experiments $(\leq 1 \mathrm{~h})$ at $1 \mathrm{GPa}$ have significantly higher $\mathrm{CO}_{2}$ concentrations in the fluid and more primary antigorite remained (Table 2), implying that carbonation was not completed. Note that the amount of $\mathrm{CO}_{2}$ in SP1 is insufficient to completely carbonate all antigorite present. In these short runs, quartz is present and the abundances of quartz and magnesite increase together from the $0.1 \mathrm{~h}$ to the $0.42 \mathrm{~h}$ run while $\mathrm{X}_{\mathrm{CO}_{2}}$ and the abundances of primary antigorite simultaneously decrease. Already after 6 min of run duration, the $\mathrm{X}_{\mathrm{CO}_{2}}$ changed from 0.5 to 0.26 and $14 \mathrm{wt} \%$ of magnesite has formed. The carbonation is complete after $1 \mathrm{~h}$ (24 wt $\%$ magnesite present) and no further changes in fluid compositions occur with longer run durations. However, the silicate phases still change proportions. In comparison to the 0.1 and $0.42 \mathrm{~h}$ experiments, we can observe that at 0.85 and $1 \mathrm{~h}$ quartz becomes less abundant and talc starts to crystallise. Talc abundances then further increase significantly between 1 to $48 \mathrm{~h}$ run while antigorite abundance decrease and magnesite remains constant. No changes to the fluid composition and phase abundances are observed after $48 \mathrm{~h}$ indicating that equilibrium has been reached.

\subsection{Trace elements and partition coefficients}

Partition coefficients for $\mathrm{Sr}, \mathrm{Pb}, \mathrm{Ba}$ and $\mathrm{Ca}$ between magnesite and a $\mathrm{CO}_{2}$-poor fluid with $0.02 \leq \mathrm{X}_{\mathrm{CO}_{2}} \leq 0.15$ have been established in the range of $500-750^{\circ} \mathrm{C}$ and $1-2 \mathrm{GPa}$. Magnesite is too fine grained to be measured individually by LA-ICP-MS. Therefore, 'bulk' 
compositions were analysed by LA-ICP-MS and the proportion of magnesite in the solid assemblage was used to obtain the trace element concentrations in magnesite. The local 'bulk' compositions have been determined using a laser spot size of $47 \mu \mathrm{m}$, which is much larger than any grain size. $\mathrm{Ca}$ was used during data reduction as the reference element. The bulk Ca-concentration was previously determined by EPMA using a defocused beam. For each sample 10 single LA-ICP-MS and EPMA spots were averaged. The abundances of magnesite (Table 2) were used to calculate the trace element composition of magnesite, assuming that negligible amounts of trace elements are incorporated into talc, chlorite and quartz (Figure S6). The trace element concentrations in the post-run fluid were subsequently established via a mass balance approach, knowing the amount of traces in the starting material, the proportions of magnesite and fluid after the experiment (Table 2) and the trace element concentration in magnesite (Table S2 and formula in the supplementary information). The partition coefficients between magnesite and fluid are within errors consistent between individual experiments in the investigated $\mathrm{P}, \mathrm{T}$ and $\mathrm{X}_{\mathrm{CO}_{2}}$ range.

Magnesite is the main host for Ca, as verified by SEM and EPMA measurements (Table S1). The positive correlation between the counts per second of $\mathrm{Ca}$ compared to $\mathrm{Ba}, \mathrm{Sr}$ and $\mathrm{Pb}$ during LA-ICP-MS analyses suggests that $\mathrm{Ba}, \mathrm{Sr}$ and $\mathrm{Pb}$ are likewise enriched in magnesite (Figure S6). Ca provided the most consistent partition coefficient with a $\mathrm{D}_{\mathrm{Ca}}^{\text {magnesite/fluid }}=$ $0.8 \pm 0.1$ (Table S2) showing that $\mathrm{Ca}$ is mildly incompatible in magnesite compared to the aqueous fluid. Similar but slightly more scattered values of $\mathrm{Sr}$ and $\mathrm{Pb}$ resulted in partition coefficients varying between 0.4 and 2.2 for $\mathrm{Sr}$ and 0.2 to 9.8 for $\mathrm{Pb}$, with medians of $\mathrm{D}_{\mathrm{Sr}}^{\text {magnesite/fluid }}=1 \pm 0.2$ and $\mathrm{D}_{P b}^{\text {magnesite/fluid }}=0.8 \pm 0.2$, respectively. It was more difficult to determine the partition coefficient for $\mathrm{Ba}$, as the concentrations in magnesite are more variable and often so high, that the fluid phase is strongly depleted in Ba. In four experiments (run 15b, 16, 16c, 30) the Ba concentration in magnesite was so high, that no $\mathrm{Ba}$ 
was left over for the fluid phase. To obtain a lower limit for these experiments, an arbitrary low Ba concentration of $200 \mathrm{ppm}$ in the fluid was assumed. The overall observations indicate that $\mathrm{Ba}$ is compatible in magnesite and partition coefficients ranged between 0.4-9.7. The median of all experiments resulted in a $\mathrm{D}_{\mathrm{Ba}}^{\text {magnesite/fluid }}$ of about 2 .

\subsection{Thermodynamic modelling}

Using the thermodynamic software package perple_X (Connolly, 2005) the binary equilibrium phase diagrams shown in Figure 6 were computed for a fixed FeO-MgO- $\mathrm{Al}_{2} \mathrm{O}_{3}-\mathrm{SiO}_{2}$ composition corresponding to the primary antigorite at 1 and $2 \mathrm{GPa}$ between $400-800^{\circ} \mathrm{C}$ assuming the system is saturated with a $\mathrm{CO}_{2}-\mathrm{H}_{2} \mathrm{O}$ fluid. The magnesite-in reaction boundary (red solid line) marks the minimum required molar proportion of $\mathrm{CO}_{2}$ in the fluid for the carbonation to start. The magnesite-in reaction (and most reactions within the magnesite stability field) has a positive slope in a $\mathrm{T}-\mathrm{X}_{\mathrm{CO}_{2}}$ isobaric diagram. Thus, at any given pressure, the required amount of $\mathrm{CO}_{2}$ in the fluid increases with increasing temperature to produce magnesite.

Magnesite is stable with quartz and an Al-rich phase at temperatures $\leqslant 550^{\circ} \mathrm{C}, 1 \mathrm{GPa}$ and elevated $\mathrm{X}_{\mathrm{CO}_{2}}$. Above $\sim 420^{\circ} \mathrm{C}$ the Al-rich phase is kyanite or chlorite. At either higher temperature at constant $\mathrm{X}_{\mathrm{CO}_{2}}$ or lower $\mathrm{X}_{\mathrm{CO}_{2}}$ at constant temperature, quartz is no longer stable and the assemblage consists of magnesite + talc + chlorite

If the $\mathrm{CO}_{2}$ concentration in the fluid is too low, carbonation will not occur. Antigorite breaks down to olivine+talc+chlorite at $1 \mathrm{GPa}$ above $550^{\circ} \mathrm{C}$. Talc stays stable until $\lesssim 660^{\circ} \mathrm{C}$ and orthopyroxene becomes abundant when temperature increases further. The assemblage of orthopyroxene + chlorite + olivine is stable towards high $\mathrm{X}_{\mathrm{CO}_{2}}$. A completely volatile free crystalline assemblage is present above $\gtrsim 770^{\circ} \mathrm{C}$ for $1 \mathrm{GPa}$. 
The systematics of the equilibrium phase stabilities at $2 \mathrm{GPa}$ are similar. When carbonation occurs, magnesite + quartz are stable together with kyanite at elevated $\mathrm{X}_{\mathrm{CO}_{2}}\left(\mathrm{X}_{\mathrm{CO}_{2}} \gtrsim 0.01\right.$ at $500^{\circ} \mathrm{C}$, respectively). Analogously to the $1 \mathrm{GPa}$ diagram, talc becomes stable and quartz disappears with either increasing temperature at constant $\mathrm{X}_{\mathrm{CO}_{2}}$ or lower $\mathrm{X}_{\mathrm{CO}_{2}}$ at constant temperature. In contrast to the low-pressure diagram, magnesite + talc can be stable together with kyanite at $2 \mathrm{GPa}$ when $\mathrm{X}_{\mathrm{CO}_{2}} \gtrsim 0.06$. Kyanite is replaced by chlorite at lower $\mathrm{X}_{\mathrm{CO}_{2}}$ (under constant temperature). At low $\mathrm{X}_{\mathrm{CO}_{2}}$ antigorite breaks down to olivine+orthopyroxene+chlorite above $650^{\circ} \mathrm{C}$. The magnesite-free assemblages occur at lower $\mathrm{X}_{\mathrm{CO}_{2}}$ at $2 \mathrm{GPa}$ compared to $1 \mathrm{GPa}$.

Besides the main stability fields described above, restricted divariant fields exist due to solid solutions relating to $\mathrm{Mg}$-Fe partitioning and tschermak exchange between coexisting phases.

Figure 6

\section{Discussion}

Our study aims to constrain the reactions and mass transfers involved in the C-O-H fluid driven carbonation of serpentinite in the slab and the forearc of subduction zones. We will first consider the approach to equilibrium of the experiments and compare the experimental results with the thermodynamic calculations. Then we discuss how equilibrium is reached, debate the potential of magnesite as monitor for trace element compositions of slab-derived fluids, and point out the implications for the deep Earth's carbon cycle.

\subsection{Approach to equilibrium}

Equilibrium was reached in runs with durations $\geq 48 \mathrm{~h}$. This is demonstrated in the time series experiments, because the assemblages crystallised and measured fluid compositions in runs with durations $\geq 48 \mathrm{~h}$ are identical within analytical uncertainty (Figure 5). The water and 
$\mathrm{CO}_{2}$ contents in the starting mixes determine the equilibrium phase assemblage, $\mathrm{X}_{\mathrm{CO}_{2}}$ in the post-run fluid and the proportion of magnesite crystallised at a given pressure and temperature (Figure 3). One assumption is that no graphite or carbonate is formed upon quenching. Matveev et al. (1997) showed that graphite saturated C-O-H fluids preserve their equilibrium C-O-H speciation during quenching from $2.4 \mathrm{GPa}$ and $1000^{\circ} \mathrm{C}$.

There is no evidence that the liberation of $\mathrm{H}_{2}$ in the dissociation of OAD has influenced the phase relations. Although $\mathrm{H}_{2}$ can diffuse out through the Pt-capsule wall (Chou et al., 1978; Harvie et al., 1980) it must be evaluated, whether significant reduction of run products occur as a result of remaining $\mathrm{H}_{2}$ in the charge. Note that the experiments were not externally buffered, but previous experiments have shown that the applied assembly imposes an $\mathrm{f}_{\mathrm{O}_{2}}$ close to the nickel-nickel oxide buffer (Hermann and Spandler, 2008). Reaction of magnetite with $\mathrm{H}_{2}$ would result in additional $\mathrm{FeO}$ available for uptake in silicate phases or formation of alloys with the Pt-capsule. The bulk Mg\# of product minerals overlaps with the Mg\# of the starting antigorite (Table S3) indicating negligible changes in the FeO content. Additionally, neither graphite in the solids nor methane in the quenched fluid was observed. These observations indicate that carbonation occurred in the presence of a $\mathrm{CO}_{2}-\mathrm{H}_{2} \mathrm{O}$ fluid.

\subsection{Comparison of experimental and thermodynamic results}

Overall the experimental results (measured $\mathrm{X}_{\mathrm{CO}_{2}}$, observed assemblages and composition) are in agreement with the thermodynamic calculations. The measured and calculated post-run fluid compositions correlate well (Figure 7), providing evidence that the post-run analyses of experimental volatiles via gas-chromatography is a viable technique (see also Martin and Hermann (in press)). Nevertheless, there are some minor discrepancies that are worth noting.

The observed phase assemblage (and hence abundances) diverges from the thermodynamically calculated assemblages, in relation to the Al-rich phase in 7 out of 21 
experiments. Kyanite is predicted by the modelling to comprise $2-4 \mathrm{wt} \%$ of the solid assemblage at high $\mathrm{X}_{\mathrm{CO}_{2}}\left(>0.03\right.$ at $\left.2 \mathrm{GPa}, 600^{\circ} \mathrm{C}\right)$, but was never observed in the experimental run products, which might be related to inhibited nucleation of kyanite. Instead chlorite was detected as the main Al phase implying that chlorite may be stable at lower water activities than thermodynamically predicted. Chromium, present in trace amounts in the serpentinite, but not considered in the thermodynamic calculations, may extend the stability of chlorite to higher $\mathrm{X}_{\mathrm{CO}_{2}}$. Cr in chlorites has found to increase with increasing $\mathrm{CO}_{2}$-concentrations in the fluid. The $\mathrm{Mg \#}$ of chlorite is higher compared to computed $\mathrm{Mg \#}$ (Table S3 for comparison of the measured and computed $\mathrm{Mg} \#$ and Al-content of solid phases). Further, the uptake of $\mathrm{Al}$ in talc may also affect chlorite stability. Although the solid solution model used for talc considers the substitution of $\mathrm{Al}$ onto the tetrahedrally coordinated site, the measured talc stoichiometry implies that $\mathrm{Al}$ occurs in both the octahedral $\left(\mathrm{Al}^{\mathrm{VI}}=0.03 \pm 0.05\right.$ apfu for 11 oxygens $)$ and tetrahedral sites $\left(\mathrm{Al}^{\mathrm{IV}}=0.08 \pm 0.05 \mathrm{apfu}\right)$ and consequently substitutes for both silicon and magnesium (supplementary information for calculation of mineral stoichiometry). Talc has incorporated more $\mathrm{Al}$ than thermodynamically predicted (Table S3). That talc can incorporate significant amounts of $\mathrm{Al}$ at elevated pressures has been shown previously (e.g. $\mathrm{Al}=0.12-0.24$ apfu at 2-1 GPa; Hoschek (1995)).

Magnesite has slightly higher Mg\# than predicted by the model (Table S3) and, in contrast to the model, no correlation between the Mg\# of magnesite and the phase assemblage could be observed. A further difference is that experimental magnesite contains $\sim 1 \mathrm{wt} \% \mathrm{CaO}$, whereas thermodynamic calculations were performed in a Ca-free system.

Although measured and calculated $\mathrm{X}_{\mathrm{CO}_{2}}$ in the fluid correlate well, it appears that the measured values are slightly higher (Figure 7). The calculated fluids are pure $\mathrm{H}_{2} \mathrm{O}-\mathrm{CO}_{2}$ fluids, whereas in the experiments other species might be present as well. Sverjensky et al. 
(2014) demonstrated that in a silicate environment, fluids are more complex and can contain additional species such as $\mathrm{HCO}_{3}^{-}$, dissolved methane or even more complex hydrocarbon molecules. $\mathrm{HCO}_{3}^{-}$could potentially be present as an additional species for the given P-T and oxygen fugacity (Sverjensky et al., 2014). Methane was not observed in quenched fluids, indicating that methane, if present, has a concentration of $\ll 1 \mathrm{wt} \%$ in the fluid (see supplementary information). Another difference between the experimental and modelled fluid compositions relates to the likely occurrence of additional, dissolved cations (e.g. $\mathrm{Si}^{4+}, \mathrm{Mg}^{2+}$, $\mathrm{Fe}^{2+}$ etc.) in the experimental fluids, which is not considered in the thermodynamic calculations. The next section shows that there is evidence for dissolved $\mathrm{Si}$ in the experimental fluids.

\section{Figure 7}

\subsection{Reaction progress and fluid composition}

Unlike the thermodynamic calculations, the time series experiments coupled with the analyses of the fluid composition provide evidence on how the carbonation reactions proceed and how the equilibrium state is reached. The high amount of $\mathrm{CO}_{2}$ in the starting fluid is the driving force of the carbonation reaction. With progressive reaction, the $\mathrm{CO}_{2}$ concentration in the fluid decreases as magnesite (sink of $\mathrm{CO}_{2}$ ) is produced and simultaneously antigorite is consumed (source of $\mathrm{H}_{2} \mathrm{O}$ ). Observed phase abundances confirm the decreasing antigorite and increasing magnesite abundances with time (Table 2). The abundance of magnesite further depends on the fluid/rock ratio (OAD to serpentinite ratio) and to a lesser extent, on pressure and temperature. The time series shows that most magnesite is formed within less than $1 \mathrm{~h}$ from the start of the experiment. Measured $\mathrm{X}_{\mathrm{CO}_{2}}$ in the fluid changes quickly within the first hour as magnesite is formed (Figure 5). Afterwards the abundance of magnesite and $\mathrm{X}_{\mathrm{CO}_{2}}$ in the fluid change insignificantly (Table 2). 
Quartz was only observed in runs $<1 \mathrm{~h}$. This indicates that antigorite breaks down initially into quartz+magnesite (4) at high $\mathrm{CO}_{2}$-concentrations in the fluid. The reaction at this point is incomplete considering that experiments that reached equilibrium contain less unreacted antigorite (Table 2).

$$
\begin{aligned}
& \mathrm{Mg}_{3} \mathrm{Si}_{2} \mathrm{O}_{5}(\mathrm{OH})_{4}+3 \mathrm{CO}_{2}=3 \mathrm{MgCO}_{3}+2 \mathrm{SiO}_{2}+2 \mathrm{H}_{2} \mathrm{O} \\
& \text { Antigorite }+3 \mathrm{CO}_{2}^{\text {fluid }}=3 \text { Magnesite }+2 \text { Quartz }+2 \mathrm{H}_{2} \mathrm{O}^{\text {fluid }}
\end{aligned}
$$

The amount of quartz found is less than expected from reaction (4). The abundance of quartz increases initially $(\leq 0.42 \mathrm{~h}$ ) and then decreases (run 59; $0.85 \mathrm{~h}$ ) until quartz completely disappears. In contrast, magnesite is continuously formed within the first hour. This implies that quartz solubility increases as the fluid becomes more aqueous.

High amounts of antigorite ( $\gtrsim 50 \mathrm{wt} \%$ ) are still present in the shortest runs, but antigorite abundance decreases over time. As carbonation seems to be completed after $\sim 1 \mathrm{~h}$, this suggests that the fluid, enriched in $\mathrm{SiO}_{2}$, reacts with antigorite to form talc according to reaction (5) until equilibrium is reached.

$$
\begin{array}{lll}
\mathrm{Mg}_{3} \mathrm{Si}_{2} \mathrm{O}_{5}(\mathrm{OH})_{4} & +2 \mathrm{SiO}_{2}^{\text {fluid }}=\mathrm{Mg}_{3} \mathrm{Si}_{4} \mathrm{O}_{10}(\mathrm{OH})_{2} & +2 \mathrm{H}_{2} \mathrm{O} \\
\text { Antigorite } & +2 \text { Quartz }^{\text {fluid }}=\text { Talc } & +2 \mathrm{H}_{2} \mathrm{O}^{\text {fluid }}
\end{array}
$$

The mass balance calculations (Table 2) additionally imply that some $\mathrm{Si}$ is dissolved in the fluid. The enrichment of Si in the fluid was further constrained by measuring the 'local' bulk composition of the solids by EPMA using a $50 \mu \mathrm{m}$ diameter defocused electron beam. The results show that the 'bulk'-solids are depleted in silica compared to the starting material by $\sim 10-20 \%$. Dissolution of silicates (eg. quartz, forsterite and olivine) in $\mathrm{COH}$-fluid is further supported by the experimental study of Tumiati et al. (2017) conducted under similar pressure and temperatures. 


\subsection{Trace element partitioning}

In addition to $\mathrm{CO}_{2}$ and dissolved silica, fluids derived from subducted altered oceanic crust and sediments contain $\mathrm{Ca}$ and fluid mobile elements like $\mathrm{Ba}, \mathrm{Sr}$ and $\mathrm{Pb}$ (Bebout et al., 2013). $\mathrm{Ba}, \mathrm{Sr}$ and $\mathrm{Pb}$ concentrations in the forearc mantle are low, but these elements are generally enriched in arc lavas compared to MORB, and isotopic studies have convincingly shown that $\mathrm{Pb}$ and $\mathrm{Sr}$ derive from the subducted crust (Elliott et al., 1997). Our study shows that $\mathrm{CO}_{2}$ might be efficiently sequestered in newly formed magnesite in the mantle wedge. An important matter is then to what extent also divalent $\mathrm{Ca}, \mathrm{Ba}, \mathrm{Sr}$ and $\mathrm{Pb}$ that can substitute for Mg could be retained in magnesites.

We have determined partition coefficients for $\mathrm{Ca}, \mathrm{Ba}, \mathrm{Sr}$ and $\mathrm{Pb}$ between magnesite and a $\mathrm{CO}_{2}$ poor hydrous fluid $\left(\mathrm{X}_{\mathrm{CO}_{2}}<0.15\right)$ for $1-2 \mathrm{GPa}$ and $500-750^{\circ} \mathrm{C}$. In this range, the partitioning is, within an uncertainty of $\sim 20 \%$ (Table S2), unaffected by a change in $\mathrm{X}_{\mathrm{CO}_{2}}$, temperature, pressure, the phase assemblage and proportions of minerals. The $\mathrm{Ca}, \mathrm{Sr}$ and $\mathrm{Pb}$ partitioning is close to unity, suggesting little $\mathrm{Ca}, \mathrm{Sr}$ and $\mathrm{Pb}$ fractionation between fluid and magnesite. Magnesite therefore can be used as a monitor for determining $\mathrm{Ca}, \mathrm{Sr}$ and $\mathrm{Pb}$ concentrations in fluids. Ba seems to be more compatible. As an example, if a fluid with an initial $\mathrm{X}_{\mathrm{CO}_{2}}$ of 0.27 (SP1; Table 1), liberated from altered oceanic crust at forearc conditions (Molina and Poli, 2000), interacts with mantle wedge serpentinites, about $30 \mathrm{wt} \%$ magnesite can be formed (Table 2). This magnesite can potentially retain about half of the original $\mathrm{Ca}$, $\mathrm{Sr}$ and $\mathrm{Pb}$ and about $70 \%$ of the initial $\mathrm{Ba}$ in the fluid. The carbonation of serpentinites thus may partially sequester fluid mobile elements from slab fluids in magnesite.

\subsection{Implications for carbon fluxes and carbon budget in the forearc}


The reaction of C-O-H bearing fluids with serpentinites in the slab and under the forearc has been investigated in this study and the results have important implications for carbon fluxes and carbon storage in the mantle.

Firstly, C-O-H fluids released from the subducting slab that migrate into the overlying, partially serpentinized mantle cause carbonation in the forearc. We have shown that carbonated serpentinite contains $\sim 30 \mathrm{wt} \%$ magnesite filtering $\sim 70$ to $95 \%$ of the initial $\mathrm{CO}_{2}$ content out of the fluid and that the carbonation of serpentinites occurs almost instantaneously. A serpentinised mantle wedge will not be coupled to the down going slab (Arcay et al., 2005) and thus over time, significant amounts of carbon can potentially be accumulated in this cold part of the mantle wedge (Figure 8).

In the following we roughly estimate the storage potential for $\mathrm{C}$ in the North Cascadia forearc mantle. We selected the North Cascadia subduction zone, because our experimentally investigated PT conditions correspond to 'hot' subduction zone geotherms likely present in the North Cascadia (Stern, 2002; Wada and Wang, 2009). For colder subduction geotherms, the $\mathrm{X}_{\mathrm{CO}_{2}}$ of fluids in equilibrium with serpentinites at the same depth is expected to be even lower (Figure 6; Kerrick and Connolly (1998)). Geophysical studies have suggested that the depression in seismic velocities would correspond to $20-30$ vol\% of serpentinization of the North Cascadia forearc mantle $\left(500-1,000 \mathrm{~km}^{2} * 1,000 \mathrm{~km}\right)$ (Hyndman and Peacock, 2003; Wada and Wang, 2009). This provides the potential to store $\sim 1-4 \mathrm{E}+07 \mathrm{MtC}$ if $30 \mathrm{wt} \%$ magnesite is formed (on average the solid post-run assemblage consists of $\sim 30 \mathrm{wt} \%$ magnesite). This amount of carbonates is presumably not detectable by seismic investigations (Sanchez-Valle et al., 2011; Yang et al., 2014). A global C-flux of 0.2-1.3 Mt/y into the leading edge of the mantle wedge has been proposed by Kelemen and Manning (2015). With a cumulative length of convergent plate margins of $55,000 \mathrm{~km}$ (Lallemand, 1999), the 
proportion of C-flux at the $1,000 \mathrm{~km}$ long North Cascadia subduction is $0.004-0.024 \mathrm{Mt} / \mathrm{y}$. Using this annual $\mathrm{C}$-flux and the lower $\mathrm{C}$-storage capacity (1E+07 $\mathrm{MtC})$ it would take 100 My to carbonate $3-20 \%$ of the serpentinites in the North Cascadia forearc mantle (Table S4) assuming pervasive fluid flow. This illustrates the potential capacity of the mantle wedge to sequester $\mathrm{CO}_{2}$ derived from the subducting slab. However, if fluid flow is channelized carbonation is likely to be less pronounced, because infiltration of subsequent fluids into unreacted serpentinites may be limited. The extent of carbonation of ultramafic rocks in the context of channelized fluid flow needs to be addressed with future studies.

Secondly, carbonation of serpentinites (and other ultramafic lithologies) within the subducting slab contributes to C-retention in the slab, because carbonates are refractory and stable even at high pressures (Brey et al., 2008; Kerrick and Connolly, 2001a; Kerrick and Connolly, 2001b; Molina and Poli, 2000; Poli et al., 2009; Yaxley and Brey, 2004; Yaxley and Green, 1994). Hence, trapping carbon first released into fluids as carbonates in the slab can supply carbon for arc magmatism and/or can lead to even deeper subduction into the convecting mantle. The mobilization of $\mathrm{C}$ into fluids and precipitation of carbonates along the fluid paths at high pressures has been inferred from several field studies of blueschist and eclogite facies rocks (Ague and Nicolescu, 2014; Collins et al., 2015; Piccoli et al., 2016; Scambelluri et al., 2016) investigating for example metacarbonate rocks, ophicarbonates or eclogite-facies marbles from the Syros and Tinos Island, Northern Apennines, Alpine Corsica or Ligurian Alps.

Thirdly, fluid driven carbonation at the subarc will be less pronounced compared to the forearc, because fluids released under the subarc already contain smaller amounts of $\mathrm{CO}_{2}$ with $\mathrm{X}_{\mathrm{CO}_{2}} \leq 0.21$ (Molina and Poli, 2000; Poli et al., 2009). Additionally, our study shows that $\mathrm{CO}_{2}$-sequestration is less efficient at higher temperatures. For example, in experiments 
performed at $2 \mathrm{GPa}$ and $700-750^{\circ} \mathrm{C}$ (run $15 \mathrm{~b}, 17$ ) the post-run fluids show $\mathrm{X}_{\mathrm{CO}_{2}}>0.1$,

537 whereas in experiments at lower temperatures and/or pressures fluids have $\mathrm{X}_{\mathrm{CO}_{2}} \ll 0.1$

538 (Table 2). At mantle wedge conditions of $3 \mathrm{GPa}, 900^{\circ} \mathrm{C}$ Tumiati et al. (2013) constrained an

$539 \mathrm{X}_{\mathrm{CO}_{2}}$ of 0.15 in fluids coexisting with a magnesite bearing garnet-peridotite and discuss

540 possible scenarios for carbon transfer from the slab to the mantle wedge. These findings together imply that $\mathrm{C}-\mathrm{O}-\mathrm{H}$-fluids travelling through the subarc mantle are less affected by a change in their carbon content and therefore most of the $\mathrm{CO}_{2}$, released into fluids under the subarc, may be transported to the source region of arc-lavas. This finding may also imply that $\mathrm{CO}_{2}$-sequestration has been less pronounced in ancient subduction zones, because ambient mantle temperatures are believed to have been higher (Nisbet et al., 1993). 
By performing piston cylinder experiments on the $\mathrm{C}-\mathrm{O}-\mathrm{H}$ fluid driven carbonation of serpentinites at pressure and temperatures corresponding to the forearc this study shows that:

- the $\mathrm{CO}_{2}, \mathrm{H}_{2} \mathrm{O}$ and alkane $\left(\mathrm{C}_{\mathrm{n}} \mathrm{H}_{2 \mathrm{n}+2}, \mathrm{n}=1-6\right.$; e.g. methane) composition of experimentally derived fluids can be successfully quantified by gas-chromatography.

- the $\mathrm{X}_{\mathrm{CO}_{2}}$ fluid composition and stable mineral assemblage can be predicted by thermodynamic modelling. Minor deviations between the modelled and observed results, however, relate to the Al-bearing phases and the assumption of a binary $\mathrm{CO}_{2}-\mathrm{H}_{2} \mathrm{O}$ fluid in the model compared to a more complex fluid composition containing dissolved Si for instance.

- carbonation of serpentinite is a rapid process, filtering $\mathrm{CO}_{2}$ from the fluid involved effectively within the first hour of the experiment. Full equilibrium is attained within 48 hours.

Our experiments have three main implications for estimating the deep Earth's carbon fluxes (Figure 8): (1) carbonation of a partially hydrated mantle wedge may establish, over time, a significant C-reservoir; (2) carbonation of serpentinite within the subducted slab contributes to $\mathrm{C}$-transfer to the deeper mantle (3) $\mathrm{CO}_{2}$-sequestration from fluids released under the subarc is likely to be less pronounced compared to the forearc and thus $\mathrm{C}-\mathrm{O}-\mathrm{H}$ fluids may migrate through the subarc mantle with only minor changes in their C-content.

Figure 8

\section{Acknowledgments}

We are grateful to U. Troitzsch, R. Rapp, P. Tollan, D. Scott and D. Clark for their assistance in analytical and experimental work. We would like to thank H. Williams and K. Evans for constructive comments and M. Bickle for the editorial handling of the paper. This study was 
569 funded by an ARC Discovery Grant (DP14010089) to G. M. Yaxley and J. Hermann, and by 570 an ANU PhD stipend to M. J. Sieber. 
Ague, J.J., and Nicolescu, S. (2014) Carbon dioxide released from subduction zones by fluid-mediated reactions. Nature Geosci, 7(5), 355-360.

Arcay, D., Tric, E., and Doin, M.P. (2005) Numerical simulations of subduction zones Effect of slab dehydration on the mantle wedge dynamics. Physics of the Earth and Planetary Interiors, 149(1-2), 133-153.

Bebout, G.E., Agard, P., Kobayashi, K., Moriguti, T., and Nakamura, E. (2013) Devolatilization history and trace element mobility in deeply subducted sedimentary rocks: Evidence from Western Alps HP/UHP suites. Chemical Geology, $342,1-20$.

Beinlich, A., Plümper, O., Hövelmann, J., Austrheim, H., and Jamtveit, B. (2012) Massive serpentinite carbonation at Linnajavri, N-Norway. Terra Nova, 24(6), 446-455.

Berner, R.A. (1999) A new look at the long-term carbon cycle. Gsa Today, 9(11), 1-6.

Bjerga, A., Konopásek, J., and Pedersen, R.B. (2015) Talc-carbonate alteration of ultramafic rocks within the Leka Ophiolite Complex, Central Norway. Lithos, 227(Supplement C), 21-36.

Brey, G.P., Bulatov, V.K., Girnis, A.V., and Lahaye, Y. (2008) Experimental melting of carbonated peridotite at $610 \mathrm{GPa}$. Journal of Petrology, 49(4), 797-821.

Caciagli, N.C., and Manning, C.E. (2003) The solubility of calcite in water at 6-16kbar and 500-800C. Contributions to Mineralogy and Petrology, 146(3), 275-285.

Chou, I.M., Eugster, H.P., Berens, P., and Weare, J.H. (1978) Diffusion of hydrogen through platinum membranes at high pressures and temperatures. Geochimica et Cosmochimica Acta, 42(3), 281-288.

Collins, N.C., Bebout, G.E., Angiboust, S., Agard, P., Scambelluri, M., Crispini, L., and John, T. (2015) Subduction zone metamorphic pathway for deep carbon cycling: II. Evidence from HP/UHP metabasaltic rocks and ophicarbonates. Chemical Geology, 412, 132-150.

Connolly, J.A.D. (2005) Computation of phase equilibria by linear programming: A tool for geodynamic modeling and its application to subduction zone decarbonation. Earth and Planetary Science Letters, 236(1-2), 524-541.

Dasgupta, R., and Hirschmann, M.M. (2010) The deep carbon cycle and melting in Earth's interior. Earth and Planetary Science Letters, 298(1-2), 1-13.

Diener, J.F.A., Powell, R., White, R.W., and Holland, T.J.B. (2007) A new thermodynamic model for clino- and orthoamphiboles in the system $\mathrm{Na} 2 \mathrm{O}-\mathrm{CaO}-\mathrm{FeO}-\mathrm{MgO}-\mathrm{Al} 2 \mathrm{O} 3-\mathrm{SiO} 2-\mathrm{H} 2 \mathrm{O}-\mathrm{O}$. Journal of Metamorphic Geology, 25(6), 631-656.

Dolejs, D., and Manning, C.E. (2010) Thermodynamic model for mineral solubility in aqueous fluids: theory, calibration and application to model fluid-flow systems. Geofluids, 10(1-2), 20-40.

Elliott, T., Plank, T., Zindler, A., White, W., and Bourdon, B. (1997) Element transport from slab to volcanic front at the Mariana arc. Journal of Geophysical Research: Solid Earth, 102(B7), 14991-15019.

Gorman, P.J., Kerrick, D.M., and Connolly, J.A.D. (2006) Modeling open system metamorphic decarbonation of subducting slabs. Geochemistry, Geophysics, Geosystems, 7(4), n/a-n/a.

Harvie, C., Weare, J.H., and O'Keefe, M. (1980) Permeation of hydrogen through platinum: A re-evaluation of the data of Chou et al. Geochimica et Cosmochimica Acta, 44(6), 899-900.

Hayes, J.M., and Waldbauer, J.R. (2006) The carbon cycle and associated redox processes through time. Philos Trans R Soc Lond B Biol Sci, 361(1470), 931-50.

Hermann, J., and Spandler, C.J. (2008) Sediment Melts at Sub-arc Depths: an Experimental Study. Journal of Petrology, 49(4), 717-740.

Holland, T., and Powell, R. (1991) A Compensated-Redlich-Kwong (Cork) Equation for Volumes and Fugacities of Co2 and H2o in the Range 1-Bar to 50-Kbar and 100-1600-Degrees-C. Contributions to Mineralogy and Petrology, 109(2), 265-273.

Holland, T.J.B., and Powell, R. (1998) An internally consistent thermodynamic data set for phases of petrological interest. Journal of Metamorphic Geology, 16(3), 309-343.

Hoschek, G. (1995) Stability relations and AI content of tremolite and tale in CMASH assemblages with kyanite + zoisite + quartz + H20. European Journal of Mineralogy, 7, 353-362.

Hyndman, R.D., and Peacock, S.M. (2003) Serpentinization of the forearc mantle. Earth and Planetary Science Letters, 212(3-4), 417-432.

Kelemen, P.B., and Manning, C.E. (2015) Reevaluating carbon fluxes in subduction zones, what goes down, mostly comes up. Proc Natl Acad Sci U S A, 112(30), E3997-4006.

Kerrick, D., and Connolly, J. (1998) Subduction of ophicarbonates and recycling of CO2 and H2O. Geology, 26(4), 375378.

-. (2001a) Metamorphic devolatilization of subducted marine sediments and the transport of volatiles into the Earth's mantle. Nature, 411(6835), 293.

Kerrick, D.M., and Connolly, J.A.D. (2001b) Metamorphic devolatilization of subducted oceanic metabasalts: implications for seismicity, arc magmatism and volatile recycling. Earth and Planetary Science Letters, 189(1), 19-29.

Lallemand, S. (1999) La subduction océanique. Pour la Science(259), 108.

Martin, L., and Hermann, J. (in press) Experimental phase relations in altered oceanic crust: implication for C recycling at subduction zones. Journal of Petrology DOI: doi.org/10.1093/petrology/egy031.

Matveev, S., Ballhaus, C., Fricke, K., Truckenbrodt, J., and Ziegenben, D. (1997) Volatiles in the Earth's mantle: I. Synthesis of CHO fluids at $1273 \mathrm{~K}$ and $2.4 \mathrm{GPa}$. Geochimica et Cosmochimica Acta, 61(15), 3081-3088. 
Molina, J.F., and Poli, S. (2000) Carbonate stability and fluid composition in subducted oceanic crust: an experimental study on H 2 O-CO 2-bearing basalts. Earth and Planetary Science Letters, 176(3), 295-310.

Nisbet, E.G., Cheadle, M.J., Arndt, N.T., and Bickle, M.J. (1993) Constraining the potential temperature of the Archaean mantle: A review of the evidence from komatiites. Lithos, 30(3-4), 291-307.

Padrón-Navarta, J.A., Sánchez-Vizcaíno, V.L., Hermann, J., Connolly, J.A.D., Garrido, C.J., Gómez-Pugnaire, M.T., and Marchesi, C. (2013) Tschermak's substitution in antigorite and consequences for phase relations and water liberation in high-grade serpentinites. Lithos, 178, 186-196.

Piccoli, F., Vitale Brovarone, A., Beyssac, O., Martinez, I., Ague, J.J., and Chaduteau, C. (2016) Carbonation by fluid-rock interactions at high-pressure conditions: Implications for carbon cycling in subduction zones. Earth and Planetary Science Letters, 445, 146-159.

Poli, S. (2015) Carbon mobilized at shallow depths in subduction zones by carbonatitic liquids. Nature Geoscience, 8(8), 633-636.

Poli, S., Franzolin, E., Fumagalli, P., and Crottini, A. (2009) The transport of carbon and hydrogen in subducted oceanic crust: An experimental study to $5 \mathrm{GPa}$. Earth and Planetary Science Letters, 278(3-4), 350-360.

Sanchez-Valle, C., Ghosh, S., and Rosa, A.D. (2011) Sound velocities of ferromagnesian carbonates and the seismic detection of carbonates in eclogites and the mantle. Geophysical research letters, 38(24).

Scambelluri, M., Bebout, G.E., Belmonte, D., Gilio, M., Campomenosi, N., Collins, N., and Crispini, L. (2016) Carbonation of subduction-zone serpentinite (high-pressure ophicarbonate; Ligurian Western Alps) and implications for the deep carbon cycling. Earth and Planetary Science Letters, 441, 155-166.

Stachel, T., and Harris, J.W. (2008) The origin of cratonic diamonds - Constraints from mineral inclusions. Ore Geology Reviews, 34(1-2), 5-32.

Stern, R.J. (2002) Subduction zones. Reviews of Geophysics, 40(4).

Sverjensky, D.A., Stagno, V., and Huang, F. (2014) Important role for organic carbon in subduction-zone fluids in the deep carbon cycle. Nature Geoscience, 7(12), 909-913.

Tiraboschi, C., Tumiati, S., Recchia, S., Miozzi, F., and Poli, S. (2016) Quantitative analysis of COH fluids synthesized at HP-HT conditions: an optimized methodology to measure volatiles in experimental capsules. Geofluids, 16(5), 841-855.

Tumiati, S., Fumagalli, P., Tiraboschi, C., and Poli, S. (2013) An Experimental Study on COH-bearing Peridotite up to $3 \cdot 2$ GPa and Implications for Crust-Mantle Recycling. Journal of Petrology, 54(3), 453-479.

Tumiati, S., Tiraboschi, C., Sverjensky, D., Pettke, T., Recchia, S., Ulmer, P., Miozzi, F., and Poli, S. (2017) Silicate dissolution boosts the CO 2 concentrations in subduction fluids. Nature communications, 8(1), 616 .

Wada, I., and Wang, K. (2009) Common depth of slab-mantle decoupling: Reconciling diversity and uniformity of subduction zones. Geochemistry, Geophysics, Geosystems, 10(10), n/a-n/a.

Yang, J., Mao, Z., Lin, J.-F., and Prakapenka, V.B. (2014) Single-crystal elasticity of the deep-mantle magnesite at high pressure and temperature. Earth and Planetary Science Letters, 392, 292-299.

Yaxley, G.M., and Brey, G.P. (2004) Phase relations of carbonate-bearing eclogite assemblages from 2.5 to 5.5 GPa: implications for petrogenesis of carbonatites. Contributions to Mineralogy and Petrology, 146(5), 606-619.

Yaxley, G.M., and Green, D.H. (1994) Experimental demonstration of refractory carbonate-bearing eclogite and siliceous melt in the subduction regime. Earth and Planetary Science Letters, 128(3-4), 313-325.

Figure 1: Relation between amount of $\mathrm{H}_{2} \mathrm{O}$ and $\mathrm{CO}_{2}$ present in the sample inlet chamber to the median signal intensity, which is the peak area of 5-7 GCTCD analyses of aliquots of the sample gas (=standard in $\mathrm{He})$.

Figure 2: SEM-EDS elemental maps (left) and BSE-images (right) of four selected runs with variable observed magnesite abundances. The distribution of $\mathrm{Mg}$ in red, $\mathrm{Si}$ in green and $\mathrm{Al}$ in blue are overlayed in each elemental map. Phases present are also indicated (ant: antigorite;

chl: chlorite; enst: enstatite; mt: magnetite; qtz: quartz). 
Figure 3: Fluid composition $\left(\mathrm{X}_{\mathrm{CO}_{2}}=\mathrm{n}_{\mathrm{CO} 2} /\left(\mathrm{n}_{\mathrm{CO} 2}+\mathrm{n}_{\mathrm{H} 2 \mathrm{O}}\right)\right.$ measured by $\mathrm{GC}-\mathrm{TCD}$ in the experiments at $1 \mathrm{GPa}$ (left) and $2 \mathrm{GPa}$ (right). Symbols refer to mineral assemblages crystallised in the experiments (mag: magnesite; chl: chlorite; ant: antigorite; qtz: quartz; enst: enstatite; fo: forsterite). Magnesite was observed in all experiments. Grey-dots represents quartz-in, yellow-dashes stands for talc-in, green-dashes/dots for the enstatite-out reaction and black points for forsterite-out (in/out in respective to increasing $\mathrm{X}_{\mathrm{CO}_{2}}$ ).

Figure 4: Ternary diagram for the $\mathrm{H}_{2} \mathrm{O}-\mathrm{SiO}_{2}+\mathrm{MgO}-\mathrm{CO}_{2}$ system, showing the starting compositions used (SP1-4; orange circles), which are mixtures between antigorite (green triangle) and oxalic acid dihydrate ( start fluid composition; blue rectangle). Observed solid run products (talc: yellow triangle; quartz + enstatite + olivine: purple triangle; magnesite: orange triangle) and $\mathrm{X}_{\mathrm{CO}_{2}}$ in post run fluids (blue diamonds) are included.

Figure 5: Measured $\mathrm{X}_{\mathrm{CO}_{2}}$ in post run fluid and change in solid assemblage over time in performed time series. Carbonation is completed after $1 \mathrm{~h}$ and full equilibrium has been reached after $\geq 48 \mathrm{~h}$.

Figure 6: Thermodynamically calculated pseudosections in the FMASCH-system using the volatile-free bulk composition of primary antigorite (Table 1) saturated with a $\mathrm{CO}_{2}$ and $\mathrm{H}_{2} \mathrm{O}$ fluid at $1 \mathrm{GPa}$ (left) and $2 \mathrm{GPa}$ (right) between $400-800{ }^{\circ} \mathrm{C}$. Colour coded boundaries refer to mineral in or out boundaries relative to increasing $\mathrm{X}_{\mathrm{CO}_{2}}$ at given temperature. Abbreviations are: Amph: Amphibole; Atg: Antigorite; Chl: Chlorite; dsp: diaspore; ky: kyanite; Mag: Magnesite; Mcar: Mg-carpholite; Ol: Olivine; Opx: Orthopyroxene; prl: pyrophyllite; q: quartz; Tlc: Talc. Phases written with a capital letter refer to solid solutions, small letters indicate endmember composition. Numbers in brackets point to restricted fields: (1) $\mathrm{Opx}+\mathrm{Chl}+\mathrm{Tlc}+\mathrm{Ol}$; (2) Amph+Chl+Tlc+Ol; (3) Chl+Tlc+Ol+Mag; (4) Chl+Tlc+Ol+Atg; (5)
Chl+Tlc+Mag+Atg;
(6) $\mathrm{Tlc}+\mathrm{Ol}+\mathrm{Mag}+\mathrm{Atg}$;
(7)
$\mathrm{Amph}+\mathrm{Tlc}+\mathrm{Ol}+\mathrm{Atg}$ 
Amph+Tlc+Mag+Atg; (9) Tlc+Mag+Atg; (10) Amph+Tlc+Atg; (11) Tlc+Atg; (12)

Chl+Tlc+Mag+Atg;

Mag+mcar+prl+qtz;

$\mathrm{Opx}+\mathrm{Chl}+\mathrm{Tlc}+\mathrm{Mag}$;

Chl+Mag+mcar+qtz;

$(14)$

Mag+mcar+qtz;

Mag+ky+mcar+qtz;

$\mathrm{Opx}+\mathrm{Chl}+\mathrm{Ol}+\mathrm{Mag}$

(19) Chl+Tlc+Mag+qtz;

$\mathrm{Opx}+\mathrm{Chl}+\mathrm{Tlc}+\mathrm{Mag}$; (22) Opx+Chl+Ol+Atg; (23) Opx+Chl+Mag+Atg; (24) Opx+Ol+Ant; (25) Opx+Mag+Ant; (26) Chl+Tlc+Mag+Atg; (27) Opx+Tlc+Mag+Atg; (28) Opx+Atg; (29) Tlc+Mag+Atg; (30) Opx+Tlc+Atg; (31) Amph+Tlc+Atg; (32) Tlc+Atg; Chl+Tlc+Mag+qtz; (34) Tlc+Mag+mcar+qtz; (35) Mag+ky+mcar+qtz; (36) Mag+mcar+qtz; (37) Chl+Mag+qtz; (38) Mag+mcar+qtz+dsp; (39) Opx+Chl+Ol+Mag; (40) Opx+Tlc+Mag; (41) Opx+Tlc+Mag+ky; (42) Tlc+Mag+ky+qtz

Figure 7: Comparison of the fluid composition as measured by GC-TCD and per thermodynamic calculations for experiments where equilibrium has been reached. The $\mathrm{X}_{\mathrm{CO}_{2}}$ values per thermodynamic modelling are obtained from Figure 6 for observed assemblages.

Figure 8 Illustration of the three main implications of the $\mathrm{COH}$ fluid driven carbonation of serpentinites under the forearc as investigated and discussed in this study. Fluids released under the forearc are high in $\mathrm{X}_{\mathrm{CO}_{2}} \leq 0.7$ (Molina and Poli, 2000) and will react with serpentinite filtering $\mathrm{CO}_{2}$ effectively in the formation of magnesite. The remaining fluids are low in $\quad \mathrm{X}_{\mathrm{CO}_{2}} \leq 0.15$ and $\sim 30 \mathrm{wt} \%$ magnesite can be formed under the forearc. This study shows that (1) carbonation might be significant under the forearc, (2) carbonation within the slab contributes to C-transfer to the deeper mantle, (3) $\mathrm{CO}_{2}$-sequestration is likely to be less pronounced at higher temperatures and pressures.

Table 1: Four starting mixes (SP1-4) with various serpentinite/fluid ratios have been used in this study. Oxalic acid dihydrate (OAD) is the main fluid source. Ba-, Sr-, Pb-, Ca-carbonate 
were added to the starting mix and are assumed to be present in the fluid in the beginning of the experiment in the listed concentrations.

730 Table 2: Overview of performed piston cylinder experiments and measured volatile composition $\left(\mathrm{X}_{\mathrm{CO}_{2}}\right)$ in the post-run fluids. The phase proportions were obtained by area analyses of BSE images and elemental maps of the solid post run assemblage in combination with the measured $\mathrm{X}_{\mathrm{CO}_{2}}$ fluid composition (see text for details). XRD has been performed on selected runs to confirm the occurrence of chlorite. 


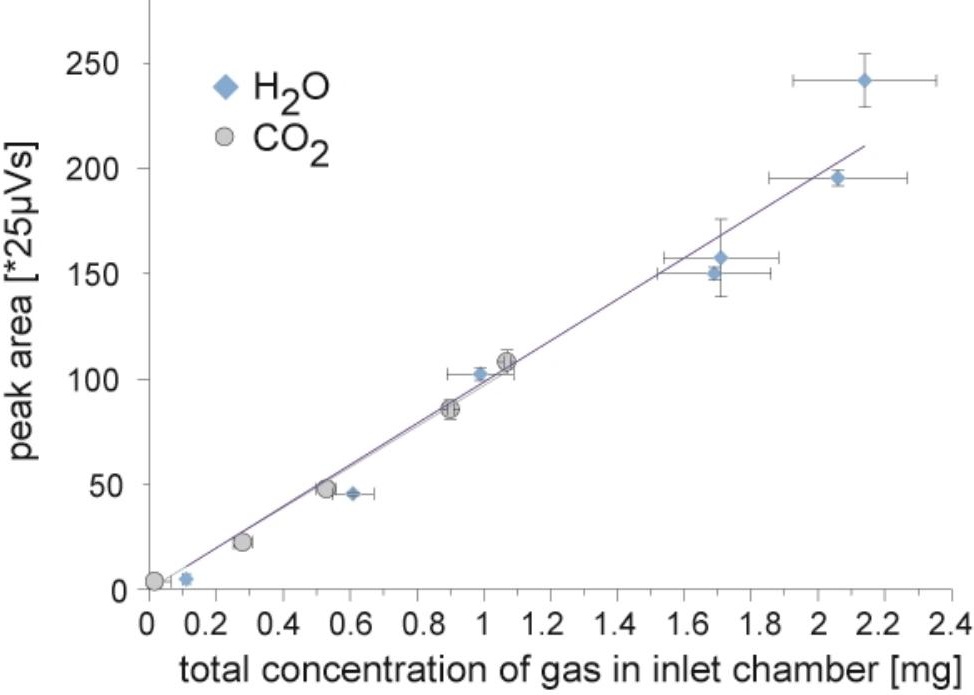


run23: SP4; $2 \mathrm{GPa} 630^{\circ} \mathrm{C} ; 48 \mathrm{~h}$

talc $>$ ant $>$ magnesite $=16 \mathrm{wt} \%>\mathrm{chl}, \mathrm{mt}$
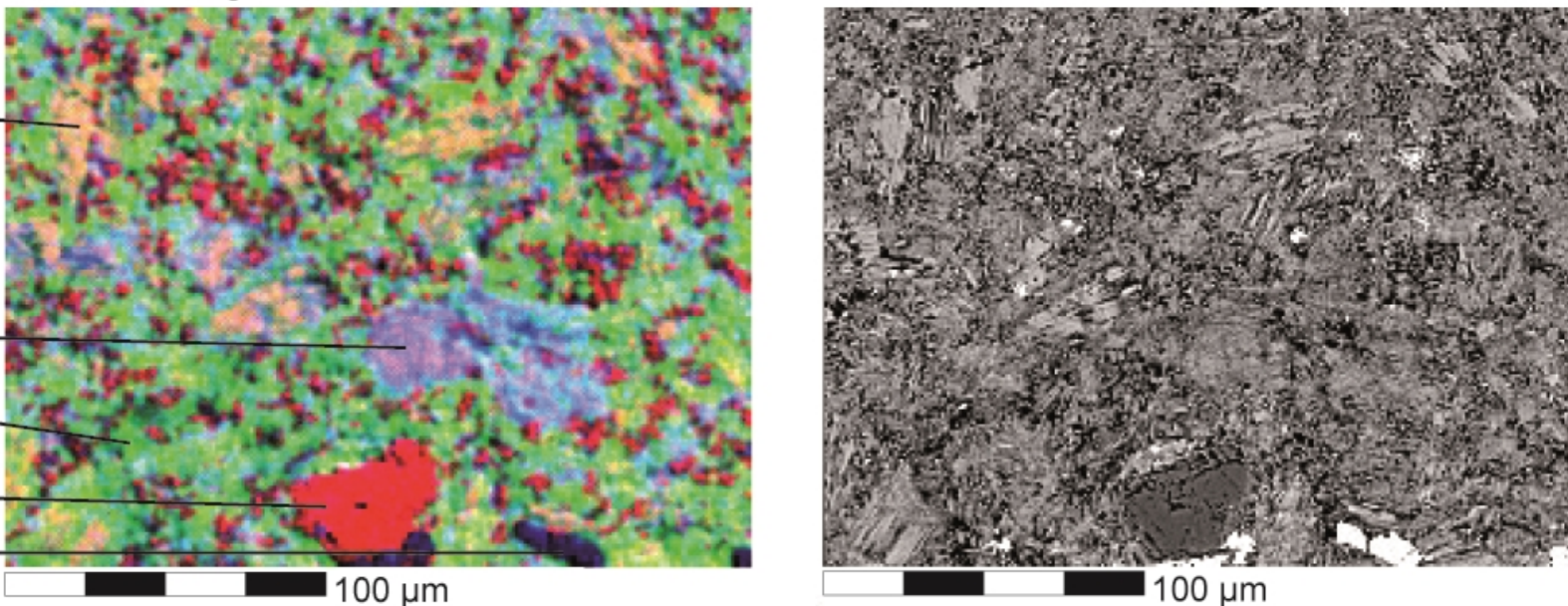

run24: SP4; $2 \mathrm{GPa} ; 700^{\circ} \mathrm{C} ; 48 \mathrm{~h}$

enst $>$ magnesite $=16 \mathrm{wt} \%>\mathrm{chl}$
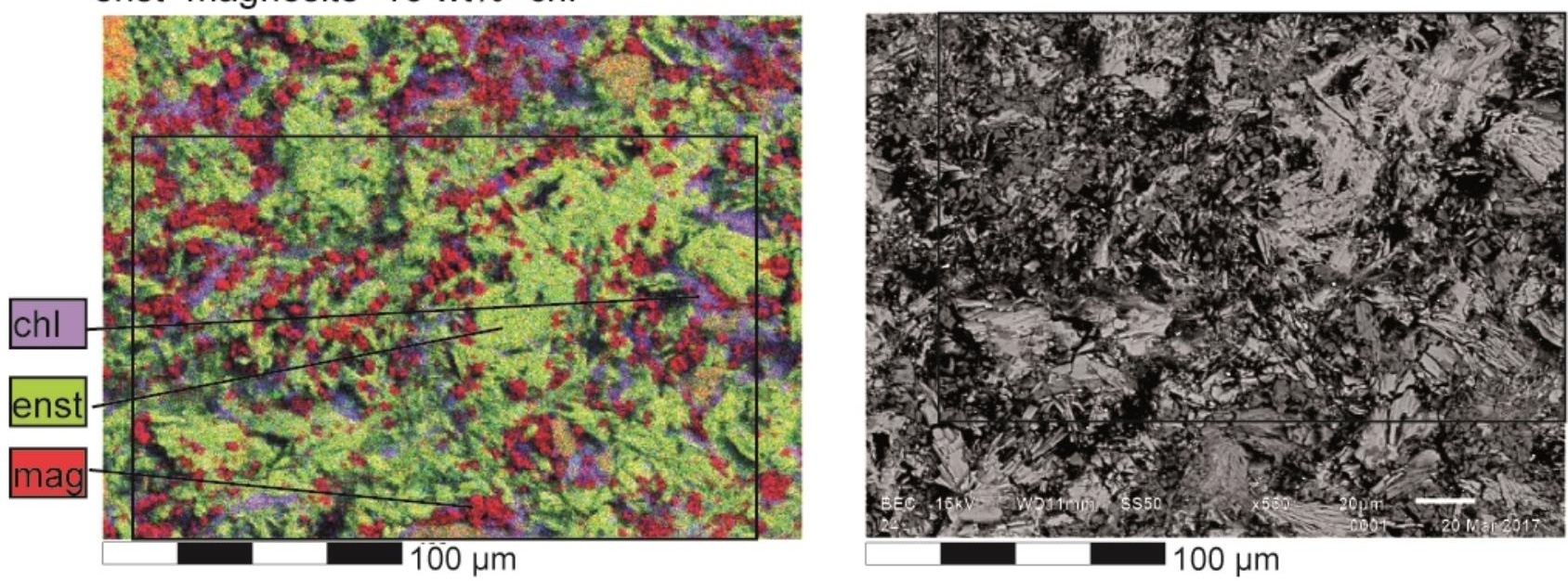

run7b: SP1; $2 \mathrm{GPa} ; 600^{\circ} \mathrm{C} ; 48 \mathrm{~h}$

talc $>$ magnesite $=24$ wt $\%>$ ant $>$ chl, $\mathrm{mt}$
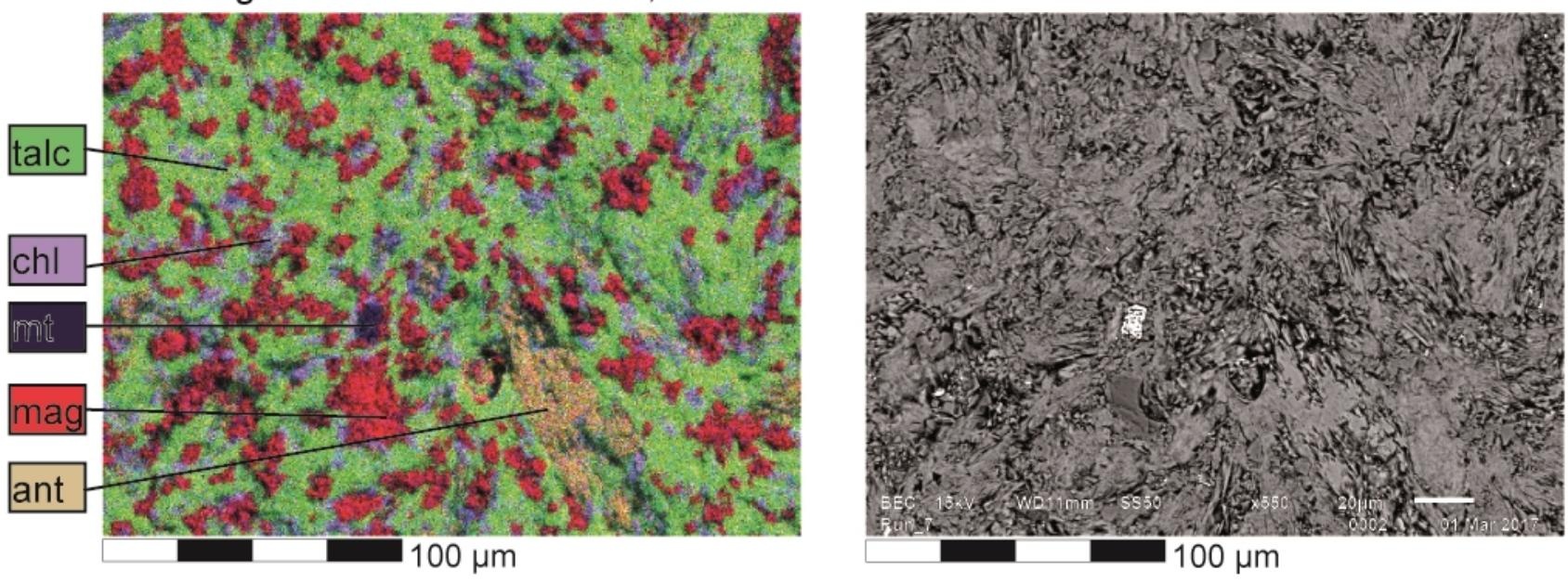

run21: SP2; $2 \mathrm{GPa} ; 600^{\circ} \mathrm{C} ; 48 \mathrm{~h}$

magnesite $=40$ wt $\%>$ talc $>$ qtz $>$ chl
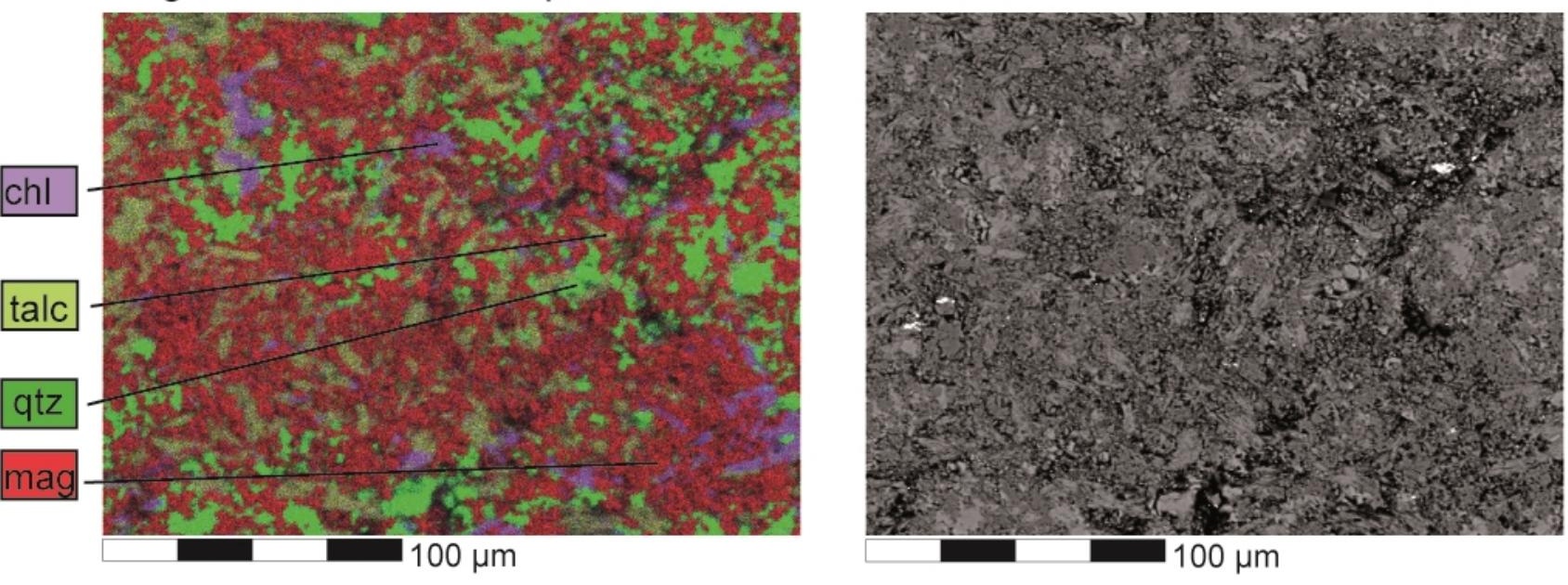


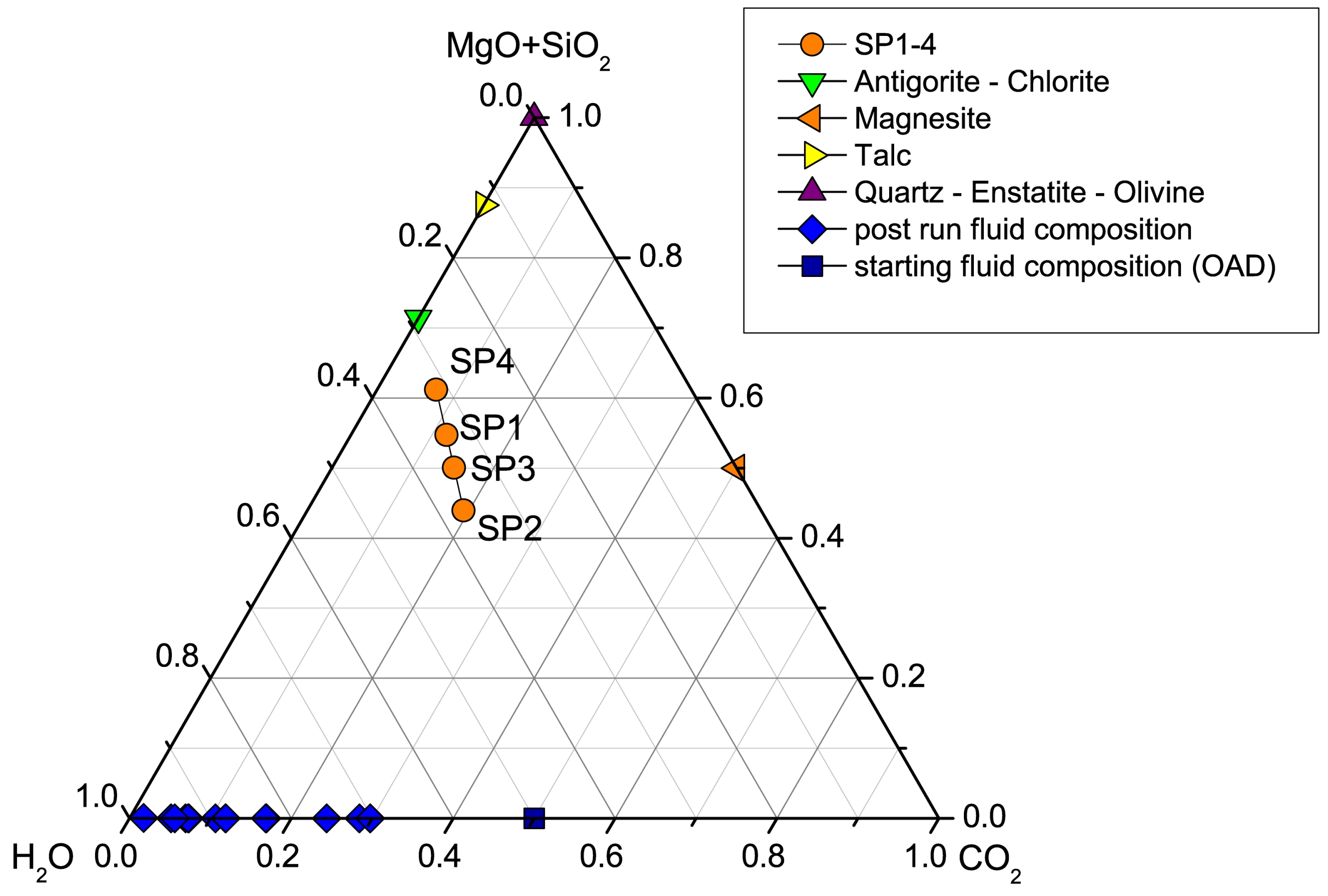




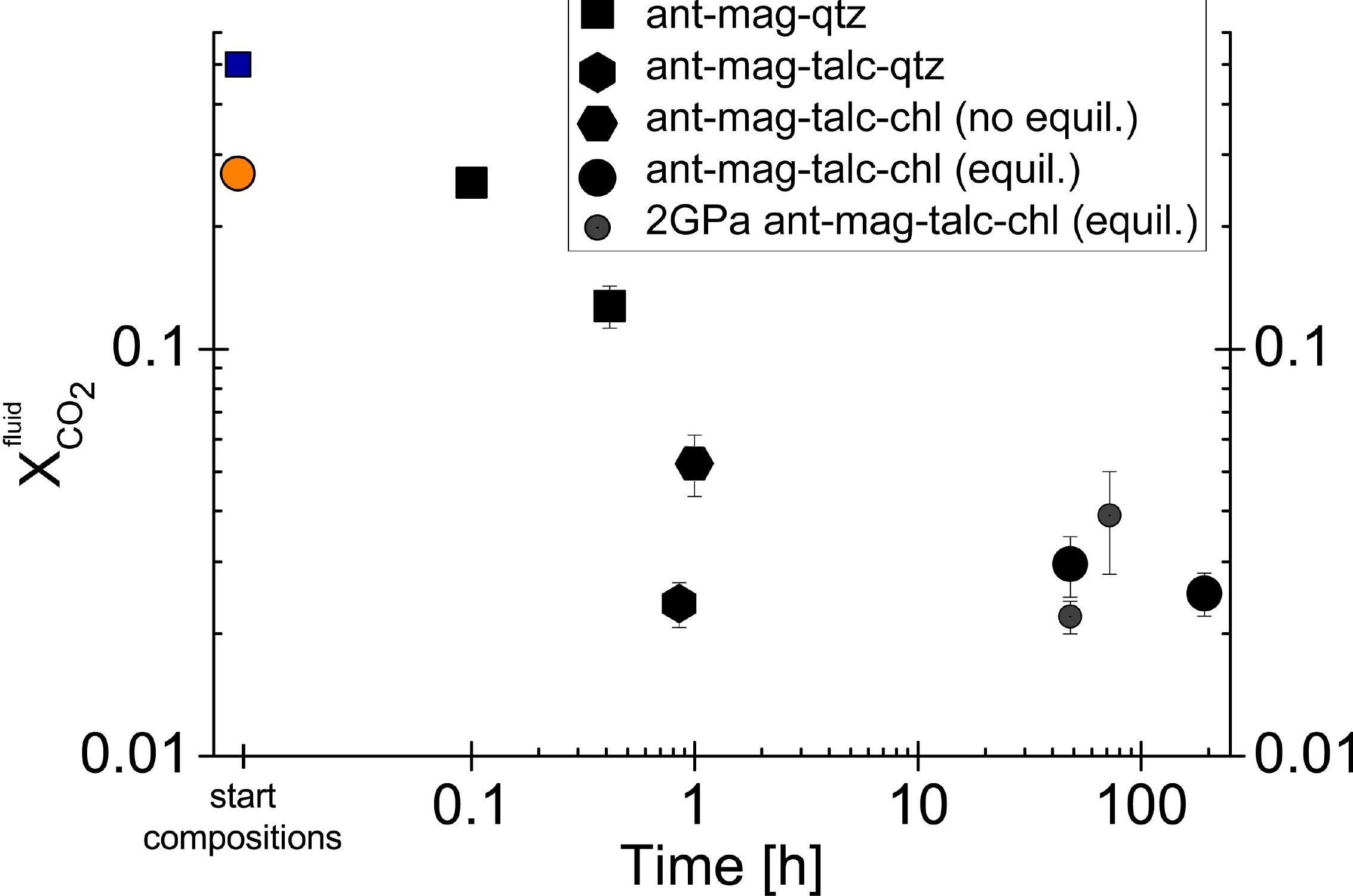




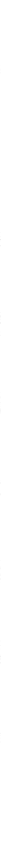




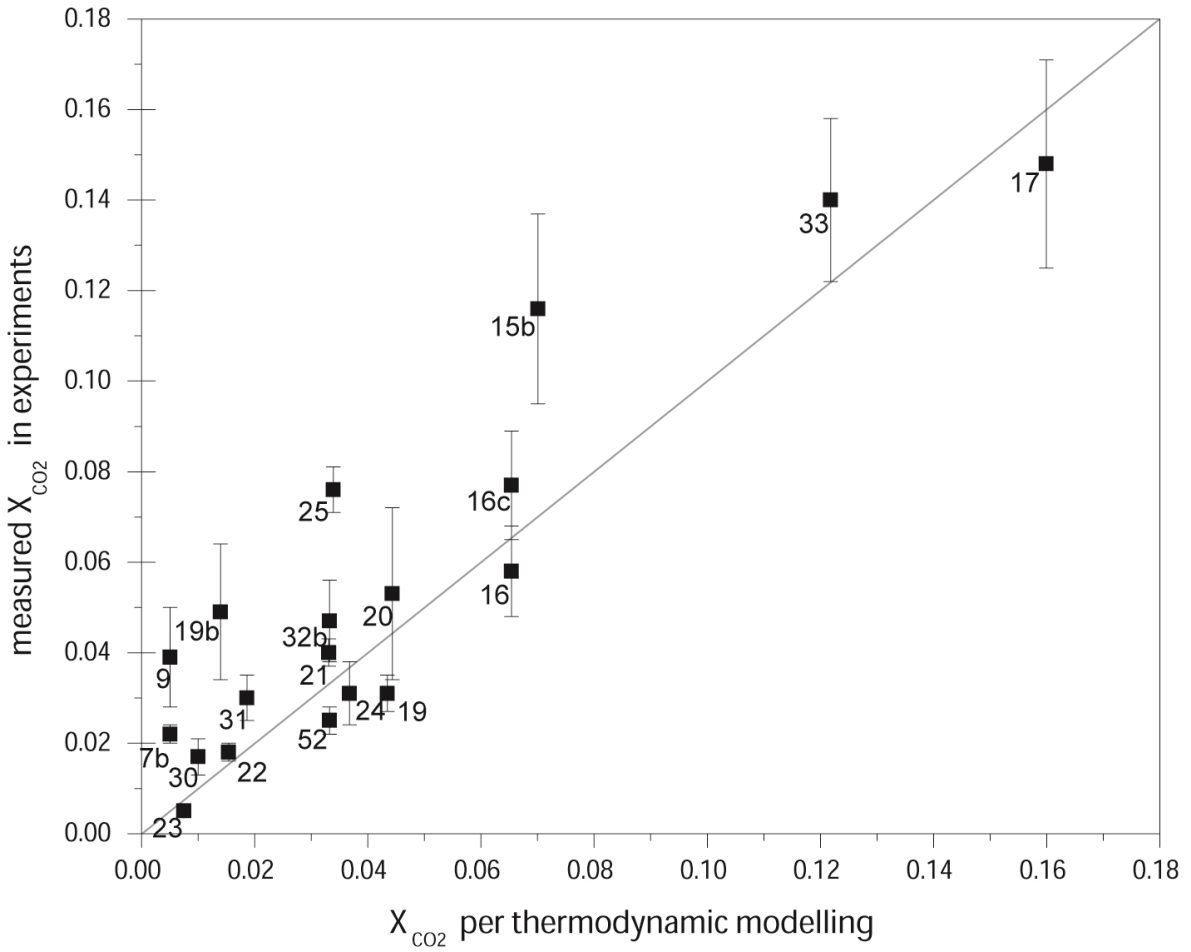




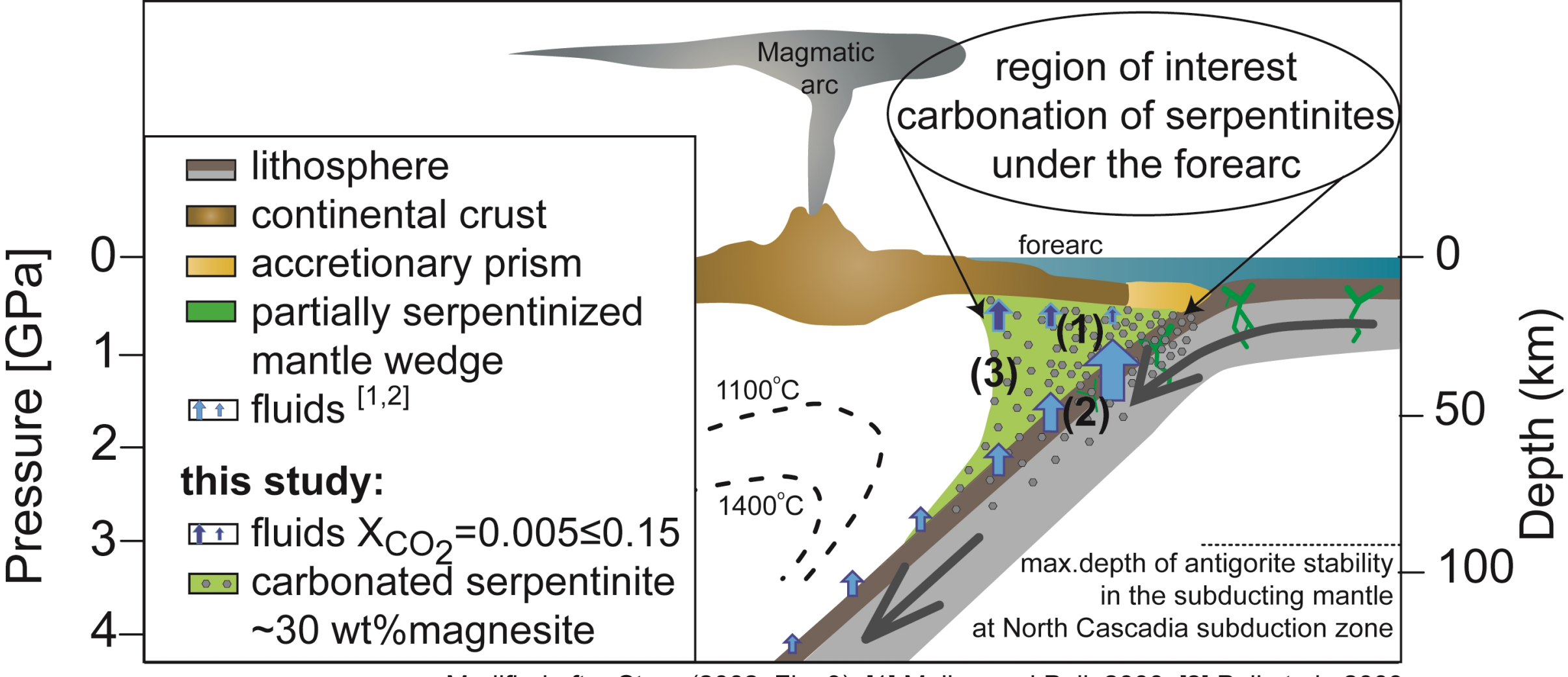


Four starting mixes (SP1-4) with various serpentinite/fluid ratios have been used in this study. Oxalic acid dihydrate $(\mathrm{OAD})$ is the main fluid source. $\mathrm{Ba}-, \mathrm{Sr}-, \mathrm{Pb}-, \mathrm{Ca}$-carbonate were added to the starting mix and are assumed to be present in the fluid in the beginning of the experiment in the listed concentrations.

\begin{tabular}{|c|c|c|c|c|c|c|c|c|c|c|}
\hline \multicolumn{3}{|c|}{ Start mix } & SP1 & $2 * \operatorname{stdev}$ & SP2 & $2 * \operatorname{stdev}$ & SP3 & $2 * \operatorname{stdev}$ & SP4 & $2 *$ stdev \\
\hline \multirow{2}{*}{\multicolumn{2}{|c|}{$\begin{array}{l}\text { Serpentinite } \\
\text { OAD }\end{array}$}} & $\mathrm{wt} \%$ & 80,0 & 0,3 & 66,4 & 0,4 & 74,3 & 0,4 & 87,8 & 0,2 \\
\hline & & $\mathrm{wt} \%$ & 19,3 & 0,3 & 33,0 & 0,4 & 25,1 & 0,3 & 11,5 & 0,2 \\
\hline \multirow{4}{*}{$\begin{array}{l}\text { Cono } \\
\text { in } \\
\text { fluid }\end{array}$} & $\mathrm{Ba}$ & $\mathrm{ppm}$ & 2118 & 21 & 1050 & 11 & 1528 & 11 & 3803 & 38 \\
\hline & $\mathrm{Ca}$ & $\mathrm{wt} \%$ & 1,32 & 0,01 & 0,65 & 0,01 & 0,95 & 0,01 & 2,33 & 0,02 \\
\hline & $\mathrm{Pb}$ & ppm & 2118 & 21 & 1050 & 11 & 1528 & 15 & 3803 & 38 \\
\hline & $\mathrm{Sr}$ & $\mathrm{ppm}$ & 2101 & 21 & 1042 & 10 & 1516 & 15 & 3772 & 38 \\
\hline \multicolumn{3}{|c|}{$\mathrm{X}_{\mathrm{CO} 2}$ bulk* } & 0,27 & 0,004 & 0,35 & 0,005 & 0,31 & 0,005 & 0,2 & 0,004 \\
\hline
\end{tabular}


Table 2

Overview of performed piston cylinder experiments and measured volatile composition $\left(\mathrm{X}_{\mathrm{CO} 2}\right)$ in the post-run fluids. The phase proportions were obtained by area analyses of BSE images and elemental maps of the solid post run assemblage in combination with the measured $\mathrm{X}_{\mathrm{CO} 2}$ fluid composition (see text for details). XRD has been performed on selected runs to confirm the occurrence of chlorite.

\begin{tabular}{|c|c|c|c|c|c|c|c|c|c|c|c|c|c|c|c|c|c|}
\hline $\begin{array}{c}\text { Run } \\
\text { No }\end{array}$ & $\begin{array}{c}\mathbf{P} \\
{[\mathrm{GPa}]}\end{array}$ & $\left.\begin{array}{c}\mathbf{T} \\
{\left[{ }^{\circ} \mathbf{C}\right]}\end{array}\right]$ & $\begin{array}{c}\text { duration } \\
\text { [h] }\end{array}$ & start mix & $\begin{array}{c}\text { start } \\
\text { weight } \\
{[\mathrm{mg}]}\end{array}$ & $\begin{array}{c}\mathbf{X}_{\mathrm{CO} 2} \\
\text { postrun } \\
\text { fluid }\end{array}$ & $\begin{array}{c}\Delta \mathbf{X}_{\mathrm{CO2}} \\
\text { postrun } \\
\text { fluid }\end{array}$ & $\begin{array}{c}\text { fluid } \\
{[w t \%]}\end{array}$ & $\begin{array}{c}\text { magnesite } \\
{[w t \%]}\end{array}$ & $\begin{array}{c}\text { talc } \\
{[\mathrm{wt} \%]}\end{array}$ & $\begin{array}{l}\text { chlorite } \\
\text { [wt \%] }\end{array}$ & $\begin{array}{l}\text { quartz } \\
{[\mathrm{wt} \%]}\end{array}$ & $\begin{array}{c}\text { antigorite } \\
\text { [wt\%] }\end{array}$ & $\begin{array}{c}\text { enstatite } \\
{[w t \%]}\end{array}$ & $\begin{array}{c}\text { forsterite } \\
{[w t \%]}\end{array}$ & $\begin{array}{c}\text { deviation } \\
\text { total mass* } \\
{[w t \%]}\end{array}$ & XRD \\
\hline 30 & 1 & 500 & 48 & SP1 & 8,9 & 0,017 & 0,004 & 22 & 24 & 39 & 2 & n.o. & 14 & n.o. & n.o. & 0 & \\
\hline 58 & 1 & 550 & 0,1 & SP1 & 65 & 0,256 & 0,013 & 12 & 14 & n.o. & n.o. & 7 & 67 & no. & no. & -4 & \\
\hline 61 & 1 & 550 & 0,42 & SP1 & 2,5 & 0,128 & 0,015 & 13 & 21 & n.o. & no. & 9 & 58 & no. & n.o. & 0 & \\
\hline 59 & 1 & 550 & 0,85 & SP1 & 11,7 & 0,024 & 0,003 & 16 & 24 & 9 & no. & 2 & 49 & no. & no. & 0 & \\
\hline 53 & 1 & 550 & 1 & SP1 & 12,0 & 0,052 & 0,009 & 20 & 23 & 12 & 2 & n.o. & 43 & n.o. & no. & -2 & \\
\hline 31 & 1,2 & 550 & 48 & SP1 & 8,2 & 0,030 & 0,005 & 23 & 23 & 43 & 2 & n.o. & 9 & n.o. & no. & 0 & \\
\hline 52 & 1 & 550 & 192 & SP1 & 80 & 0,025 & 0,003 & 28 & 24 & 40 & 1 & n.o. & 8 & n.o. & no. & 0 & \\
\hline $32 \mathrm{~b}$ & 1 & 600 & 48 & SP1 & 8,1 & 0,047 & 0,009 & 15 & 24 & 49 & 2 & n.o. & 10 & n.o. & n.o. & 1 & \\
\hline 33 & 1 & -650 & 48 & SP1 & 7,5 & 0,140 & 0,018 & 23 & 17 & 46 & 1 & noo. & 13 & n.o. & no.- & 0 & \\
\hline 22 & 2 & 550 & 48 & SP1 & 111 & 0,018 & 0,002 & 20 & 24 & 50 & 2 & 4 & no- & n.o. & no. & 0 & \\
\hline 8 & 2 & 600 & 24 & SP1 & 11,0 & n.a. & & n.a. & present & present & present & n.o. & present & n.o. & n.o. & u.c. & \\
\hline 7 & 2 & 600 & 48 & SP1 & 12,5 & n.a. & & n.a. & present & present & present & n.o. & present & n.o. & n.o. & u.c. & \\
\hline $7 \mathrm{~b}$ & 2 & 600 & 48 & SP1 & 9,6 & 0,022 & 0,002 & 24 & 24 & 44 & 2 & n.o. & 6 & no. & no. & 0 & $\mathrm{y}$ \\
\hline 9 & 2 & 600 & 72 & SP1 & 12,0 & 0,039 & 0.011 & 12 & 24 & 44 & 3 & no. & 18 & no. & no. & 3 & \\
\hline 21 & 2 & 600 & 48 & SP2 & 11,7 & 0,040 & 0,003 & 36 & 40 & 15 & 2 & 8 & no. & no. & no. & $-0,1$ & \\
\hline 23 & 2 & 630 & 48 & SP4 & 12,6 & 0,005 & 0.001 & 11 & 16 & 64 & 4 & noo & 6 & no. & no. & 7 & \\
\hline 19 & 2 & 650 & 48 & SP3 & 8,6 & 0,031 & 0,004 & 16 & 34 & 48 & 2 & n.o. & no. & no. & no. & 9 & $\mathrm{y}$ \\
\hline $19 \mathrm{~b}$ & 2 & 650 & 48 & SP3 & 9,2 & 0,049 & 0,015 & 21 & 32 & 31 & 2 & n.o. & 14 & n.o. & n.o. & 6 & \\
\hline 16 & 2 & 650 & 53 & SP2 & 5,5 & 0,058 & 0.010 & 19 & 38 & 24 & 3 & 16 & no. & no. & no. & 0 & \\
\hline $16 \mathrm{c}$ & 2 & 650 & 48 & SP2 & 6,6 & 0,077 & 0,012 & 21 & 39 & 17 & 3 & 20 & n.o. & n.o. & no. & 0 & $y$ \\
\hline 24 & 2 & 700 & 48 & SP4 & 135 & 0,031 & 0.007 & 18 & 16 & no. & 2 & no. & n.o. & 64 & no. & 19 & \\
\hline 20 & 2 & 700 & 48 & SP3 & 143 & 0,053 & 0,019 & 19 & 29 & 45 & 0,4 & no. & 4 & 2 & no. & 04 & $\mathrm{y}$ \\
\hline $15 \mathrm{~b}$ & 2 & 700 & 48 & SP2 & 8,3 & 0,116 & 0,021 & 24 & 34 & 40 & 3 & n.o. & n.o. & n.o. & no. & 0,4 & $\mathrm{y}$ \\
\hline 25 & 2 & 750 & 48 & SP4 & 13,6 & 0,076 & 0,005 & 30 & 11 & no. & 3 & noo. & n.o. & 36 & 20 & 9 & \\
\hline 17 & 2 & 750 & 48 & SP2 & 10,3 & 0,148 & 0,023 & 24 & 31 & 43 & 2 & n.o. & n.o. & n.o. & n.o. & 0 & \\
\hline
\end{tabular}

Devistion of the total mass after mass-balance compared to the stat weight.

n.a.: not analysed; n.o.: not observed; y: XRD measurement has been performed and the occurrence of chlorite was verified 